\title{
Isolation of Lytic Bacteriophages against MDR-Klebsiella pneumoniae and MDR-Enterobacter aerogenes from Sewage Samples: A Potential Tool for Medical Purposes
}

\author{
Fatemeh Habibinava ${ }^{1}$, Mohammad Reza Zolfaghari ${ }^{1 *}$, Saleheh Sabouri ${ }^{2}$, Mohsen Zargar ${ }^{1}$, \\ Mohammad Soleimani ${ }^{3}$
}

1. Department of Biology, Qom Branch, Islamic Azad University, Qom, Iran

2. Pharmaceutical Biotechnology, Faculty of Pharmacy, Kerman, University of Medical Sciences, Kerman, Iran

3. Department of Microbiology, Faculty of Medicine, AJA University of Medical Sciences, Tehran, Iran

\section{ABSTRACT}

Background and Aim: This study aimed to isolate phages able to lyse some strains of multiple drug-resistant (MDR)-Klebsiella pneumoniae (named vB_Kp1 and vB_Kp2) and Enterobacter aerogenes (named vB_Ea1) from swage.

Materials and Methods: Different $K$. pneumoniae and $E$. aerogenes strains were isolated from clinical specimens during January-September 2018 in three hospitals of Amol, Mazandaran, Iran. Kirby-Bauer disc diffusion method was used to determine the resistance profiles of these isolates using different antibiotics. The MDR strains were selected for investigating the effect of isolated phages from wastewater and hospital sewage. The presence of phage was confirmed by plaque formation. The isolated bacteriophages were enriched, concentrated, and stained. Afterwards, a transmitting electron microscope (TEM) was applied to observe the morphology of the bacteriophages. Phage identification tests, including host range and one-step growth, were performed.

Results: The TEM analysis revealed that three phages had an icosahedral capsid and long contractile tail being classified as a member of the Myoviridae family. Phages were able to lyse 14 (56\%) of the 25 MDR isolated bacterial strains. The onestep growth curve showed large bursts and short latent times.

Conclusion: The formation of clear plaques demonstrates the high lyse power of phages. Therefore, they have good potential for further analysis for clinical use as a therapeutic agent in the future.

Keywords: Enterobacter aerogenes, Klebsiella pneumoniae, Multiple drug-resistant infections, Phage therapy

Received: 2020/09/16; $\quad$ Accepted: 2020/11/02; Published Online: 2021/01/10

Corresponding Information: Mohammad Reza Zolfaghari, , Qom Branch, Islamic Azad University, Qom, Iran.

Corresponding Information: Email:mreza.zolfaghary@gmail.com

Copyright (c) 2021, This is an original open-access article distributed under the terms of the Creative Commons Attribution-noncommercial 4.0 International License which
permits copy and redistribution of the material just in noncommercial usages with proper citation.

Use your device to scan and read the article online

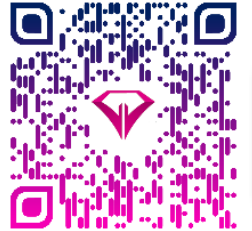

Habibinava F, Zolfaghari M R, Sabouri Shahrbabak S, Zargar M, Soleimani M. Isolation of Lytic Bacteriophages from Sewage Samples against MDR-Klebsiella pneumoniae and MDR-Enterobacter aerogenes: A potential tool for medical purposes. Iran J Med Microbiol. 2021; 15 (1) 46-66

\section{Download citation: BibTeX | RIS | EndNote | Medlars | ProCite | Reference Manager | RefWorks}
Send citation to:
8 Mendeley
2 Zotero
(B) RefWorks

\section{Introduction}

One of the most significant problems in global health in the last decade has been the increasing prevalence of antibiotic-resistant infections, including gram-positive and gram-negative bacteria, specifically the "ESKAPE" bacteria (i.e., Enterococcus faecium,
Staphylococcus aureus, Klebsiella pneumoniae, Acinetobacter baumannii, Pseudomonas aeruginosa, and Enterobacter spp.) (1, 2). Excessive usage of antibacterial drugs might result in elevated 
multipledrug resistance (MDR) infections and changes in the bacterial population in patients (3).

Gram-negative bacteria, such as $E$. aerogenes and $K$. pneumonia are resistant to cephalosporin, penicillin, and carbapenem family leading to MDR infection formation. $E$. aerogenes and $K$. pneumoniae can express carbapenemase (KPC), extended-spectrum beta-lactamase (ESBL), and metal beta-lactamase that have not been defined as a class of antibiotics capable of controlling the infection (4-7).

Gram-negative MDR contamination in individuals with poor immune systems, such as infants, elderlies, immunosuppressed cases, and cancer patients, is a real danger that results in extreme neutropenia symptoms and even death in some cases $(3,8)$. The rising prevalence of MDR infections, treatment difficulties, and extended therapy has led to the production of high-efficiency new antibacterial medications with lower side effects and low cost for the management of MDR infections.

An alternative that has gained a lot of interest in the last two decades is bacterial viruses or bacteriophages discovered almost a century ago $(9,10)$. One type is lytic phages that enter into bacterial cells and change bacterial metabolism causing bacteriolysis and destruction $(9,11)$. Since the early 20th century, phage therapy has been used as an agent for the treatment of infections caused by both gram-positive and gramnegative bacteria (9-11).

Considering the benefit of phage therapy, several European countries and the United States have started to discover new bacteriophages for the antibacterial management of drug-resistant infections and seriously infected patients (12-14). Some preferences of phage therapy entail efficacy in treating MDR infections, not destroying the natural microbial flora of the patient, lower costs of phage therapy relative to broad-spectrum antibiotics, fewer side effects, stability in unfavorable temperature and drought conditions, specificity for the target bacteria, lacking toxin genes, and easy isolation from diverse environmental samples, such as sewage, sea, and dirt (15-18).

The objective of the present study was to screen and isolate lytic bacteriophages from sewage, which can be useful for the antibiotic-resistant strains of $K$. pneumoniae and $E$. aerogenes isolated from clinical specimens.

\section{Materials and Methods}

\section{Bacterial Strains}

$K$. pneumoniae and $E$. aerogenes were isolated from the clinical specimens of three hospitals and medical centers in Amol, Mazandaran, Iran during January-
September 2018. Isolated bacteria were analyzed using biochemical tests according to the American Society for Microbiology standard methods to confirm the bacterial strain. Moreover, P. aeruginosa ATCC 1074, S. aureus ATCC 6538, E. coli ATCC 35218, Salmonella typhi PTCC 1639, E. aerogenes PTCC 1221, and $K$. pneumoniae PTCC 1290 were obtained from the microbial collection of Pasteur Institute of Iran and were used as the standard strains.

\section{Antimicrobial Susceptibility Testing}

Antibiotic susceptibility patterns were assessed by the Kirby-Bauer disk diffusion method on MuellerHinton agar. The susceptibility of bacteria was classified based on the Clinical and Laboratory Standards Institute guidelines (19). Twelve different kinds of antibiotics were utilized, including amikacin (30 $\mu \mathrm{g})$, cefotaxime (30 $\mathrm{\mu g})$, ciprofloxacin (5 $\mu \mathrm{g})$, chloramphenicol $(30 \mu \mathrm{g})$, gentamycin $(10 \mu \mathrm{g})$, cefalotin $(10 \mu \mathrm{g})$, imipenem $(10 \mu \mathrm{g})$, nitrofurantoin $(300 \mu \mathrm{g})$, cotrimoxazole $(5 \mu \mathrm{g})$, tetracycline $(30 \mu \mathrm{g})$, norfloxacin $(10 \mu \mathrm{g})$, and nalidixic acid $(30 \mu \mathrm{g})$ (Merck, Germany).

The strains resistant to at least three classes of antimicrobial agents were considered as MDR bacteria (19). Finally, 15 MDR-K. pneumoniae and 10 MDR-E. aerogenes were obtained from clinical isolates (Table 1). Approximately 2-3 colonies were suspended with $100 \mathrm{ml}$ sterile physiological serum and were incubated at $37^{\circ} \mathrm{C}$ to adjust the bacterial density equal to that of $0.5 \mathrm{McF}$ arland turbidity reference.

\section{Phage Isolation and Propagation}

Hospital, industrial, and urban wastewater samples were collected from a different place in Mazandaran, north of Iran during January-September 2018 (Table 2). Samples were collected in a sterile falcon and then centrifuged at $5000 \mathrm{~g}$ for $10 \mathrm{~min}$ (RS/20IV, TPMYSELKO, Japan) to remove large particulates. The supernatant was filtered using $0.22 \mu \mathrm{m}$ syringe filters (Startech, Taiwan) and stored at $4^{\circ} \mathrm{C}$. To enrich the bacteriophage (21), we added $10 \mathrm{ml}$ of each sample supernatant into $100 \mathrm{ml}$ exponential growth cultures (in early log phase, OD of 0.4-0.6) supplemented with $0.1 \mathrm{M}$ calcium chloride (Merck, Germany). The cultures were incubated in a shaker incubator (JAL company, Iran) at $37^{\circ} \mathrm{C}$ and $40 \mathrm{rpm}$ for $48 \mathrm{~h}$. Next, the samples were centrifuged at $5000 \mathrm{rpm}$ for $15 \mathrm{~min}$ and the supernatant was filtered through a $0.22 \mu \mathrm{M}$ syringe filter (22). 
Table 1. MDR-K. pneumonia and MDR-E. aerogenes obtained from clinical isolates

\begin{tabular}{|c|c|c|c|c|}
\hline Microorganism & Source & Sample origin & Number of samples & Abbreviation \\
\hline K. pneumoniae & Imam Reza Hospital & $\begin{array}{l}\text { Urine } \\
\text { Urine } \\
\text { Blood } \\
\text { Urine } \\
\text { Urine } \\
\text { Chip } \\
\text { Urine } \\
\text { Blood } \\
\text { Urine } \\
\text { Wounds }\end{array}$ & 10 & $\begin{array}{l}\text { Kr1 } \\
\text { Kr2 } \\
\text { Kr3 } \\
\text { Kr4 } \\
\text { Kr5 } \\
\text { Kr6 } \\
\text { Kr7 } \\
\text { Kr8 } \\
\text { Kr9 } \\
\text { Kr10 }\end{array}$ \\
\hline K. pneumoniae & Imam Ali Hospital & $\begin{array}{l}\text { Urine } \\
\text { Wounds } \\
\text { Blood } \\
\text { Urine } \\
\text { Wounds }\end{array}$ & 5 & $\begin{array}{l}\text { Ka1 } \\
\text { Ka2 } \\
\text { Ka3 } \\
\text { Ka4 } \\
\text { Ka5 }\end{array}$ \\
\hline E. aerogenes & Imam Reza Hospital & $\begin{array}{l}\text { Urine } \\
\text { Urine } \\
\text { Wounds } \\
\text { Urine } \\
\text { Chip }\end{array}$ & 5 & $\begin{array}{l}\text { Er1 } \\
\text { Er2 } \\
\text { Er3 } \\
\text { Er4 } \\
\text { Er5 }\end{array}$ \\
\hline E. aerogenes & $\begin{array}{c}\text { Imam Mosabn Jafar } \\
\text { Hospital }\end{array}$ & $\begin{array}{l}\text { Urine } \\
\text { Urine } \\
\text { Wounds } \\
\text { Urine } \\
\text { Blood }\end{array}$ & 5 & $\begin{array}{l}\text { Em1 } \\
\text { Em2 } \\
\text { Em3 } \\
\text { Em4 } \\
\text { Em5 }\end{array}$ \\
\hline
\end{tabular}

Table 2. Place of collection of wastewater samples

\begin{tabular}{|cc|}
\hline $\mathbf{S a m p l e}$ number & Sampling location \\
\hline $\mathbf{2}$ & Sewage outlet of Amirkola Children's Hospital \\
\hline $\mathbf{3}$ & Sepidan poultry slaughterhouse wastewater outlet \\
\hline $\mathbf{4}$ & Oil Company effluent (Mahmoud Abad) \\
\hline $\mathbf{5}$ & Sewage of Cheshmeh Saran fish breeding pool \\
\hline $\mathbf{6}$ & Sewage of North Pardis Recreation Complex \\
\hline $\mathbf{7}$ & Wastewater outlet of Ghaem Hospital (Kelardasht) \\
\hline $\mathbf{8}$ & North Hospital (Amol) \\
\hline $\mathbf{9}$ & Imam Hossein Hospital (Neka) \\
\hline 10 & Omidi Hospital (Behshahr) \\
\hline $\mathbf{1 1}$ & Bmam Hospital (Behshahr) \\
\hline
\end{tabular}

\section{Double-Layer Agar Technique (Plaque Assay)}

We used the double-layer agar (DLA) method to examine the antibacterial ability of the isolated phages. To this end, $200 \mu \mathrm{L}$ of bacterial culture early log phase $(O D=0.2-0.4)$ and $200 \mu \mathrm{L}$ of filtrates supernatant were mixed and incubated for $15 \mathrm{~min}$ at $37^{\circ} \mathrm{C}$ for proper absorption. The medium was mixed with $3 \mathrm{ml}$ of LB soft agar containing $0.7 \%$ half agar (Merck, Germany) and was poured onto the bottom agar followed by swirling to produce a uniform top layer. The plates were incubated overnight at $37^{\circ} \mathrm{C}$.
The lysis zones or plaque formation after incubation suggested the presence of lytic phages (23).

\section{Phage Purification}

Each plaque formed on the plate surface contains approximately $10^{5}-10^{6}$ phages. The established plaque was solved in $1.5 \mathrm{~mL}$ of LB solution. Afterwards, 200 $\mu \mathrm{L}$ of chloroform was added to eliminate bacterial contaminations according to the method mentioned in the phage isolation section. For better purification, plaque assay was performed in triplicate. The titers of each phage, isolated against MDR-bacteria from clinical samples, were represented in plaque-forming 
units (PFU) per $\mathrm{mL}(\mathrm{PFU} / \mathrm{mL}$ ) as described by Carlson and Miller (24).

\section{Determination of Host Range}

Spot assay was applied for determining the host range of purified bacteriophage (25). Different bacteria isolated from clinical specimens and indicator bacteria strains were grown in LB broth until the early log phase $(O D=0.4)$. Next, $300 \mu \mathrm{L}$ of bacteria were mixed with $0.5 \%$ LB agar infused onto the underneath $1 \%$ LB agar to solidify. Afterwards, $10 \mu \mathrm{L}$ of several dilutions of purified phage $\left(10^{7}, 10^{5}, 10^{3}\right.$, and $10^{1}$ $\mathrm{PFU} / \mathrm{mL}$ ) was dropped on the LB agar. The plates were incubated overnight at $37^{\circ} \mathrm{C}$. The lysis zones or plaque formation were analyzed after incubation.

\section{Phage Adsorption Assays}

Diverse bacteria isolated from clinical samples were cultured overnight in LB at $37^{\circ} \mathrm{C}$. Approximately $10^{7}$ $\mathrm{PFU} / \mathrm{mL}$ of isolated and purified phage in $500 \mu \mathrm{L}$ was mixed with $500 \mu \mathrm{L}$ of bacterial samples, about $10^{8}$ $\mathrm{CFU} / \mathrm{mL}$. The suspension was incubated at $37^{\circ} \mathrm{C}$ and the medium was centrifuged at $8000 \times \mathrm{g}$ for $3 \mathrm{~min}$ after $0,2,4,6,8,10$, and $12 \mathrm{~min}$. The phage titer that remained in the supernatant was examined by the DLA method. The isolated bacteria cultured in LB was exclusively utilized as a non-absorbing control.

\section{Determine the Optimal Multiplicity of Infection}

To determine the optimal multiplicity of infection (MOI) required for attaining maximum adsorption without affecting bacterial viability (26), $10^{4}$ bacteria (in early log phase, $\mathrm{OD}=0.3$ ) were cultured in a 96 well plate and mixed with several dilutions of phage $\left(10^{7}\right.$, $10^{6}, 10^{5}, 10^{4}, 10^{3}$, and $10^{2} \mathrm{PFU} / \mathrm{mL}$ ). MOls were assessed at $2 \mathrm{hr}, 4 \mathrm{hr}$ and $8 \mathrm{hr}$ after infection. The experiments were performed in triplicate. The wells containing exclusively bacteria or phage were considered as controls. The turbidity of each well was measured with a microplate enzyme-linked immunosorbent assay reader (ELX800, BioTek Instruments, USA) at $630 \mathrm{~nm}(O D=630)$. The best results were adopted for our phage further analysis.

\section{One-step Growth Curve Analysis}

Host bacteria were cultured in $10 \mathrm{ml}$ LB broth until reaching the early log phase $(O D=0.3)$. Afterwards, the cultured bacteria were centrifuged at $5000 \times \mathrm{g}$ for 10 min, the supernatant was discarded, and the pellet was resuspended (contain bacteria) in $1 \mathrm{~mL}$ LB broth. The phage suspension was mixed with bacteria culture medium according to $\mathrm{MOI}$ (Table 3 ) and the suspension was incubated at room temperature for 10 min for phage adsorption.

Following incubation, the non-adsorbed phage was deleted by centrifugation at $11000 \times \mathrm{g}$ for $30 \mathrm{sec}$ and the pellet containing adsorbed phage was suspended in $10 \mathrm{ml}$ of LB broth. The phage titer in the culture was determined every $10 \mathrm{~min}$. The phage was purified using chloroform according to the method described in the phage isolation section (27).

Table3. General characteristics of 3 bacteriophages isolated from wastewater samples

\begin{tabular}{|c|c|c|c|}
\hline Characteristics & vB-Kp1* & vB-Kp2 & vB-Ea1** \\
\hline Host bacteria & K. pneumoniae & K. pneumoniae & E. aerogenes \\
\hline $\mathrm{PFU} / \mathrm{ml}$ & $15 \times 10^{10}$ & $3 \times 10^{11}$ & $3 \times 10^{12}$ \\
\hline Plaque appearance & Clear & Clear & Clear \\
\hline MOI & $10^{3}$ & $10^{1}$ & $10^{3}$ \\
\hline Latent period (min) & 20 & 10 & 10 \\
\hline Burst size & 500 & 833 & 333 \\
\hline Family & Myoviridae & Myoviridae & Myoviridae \\
\hline Head diameter $(\mathrm{nm})$ & 40 & 45 & 70 \\
\hline Tail length (nm) & 70 & 80 & 110 \\
\hline Sampling location & $\begin{array}{l}\text { Sewage outlet of Amirkola } \\
\text { Children's Hospital }\end{array}$ & $\begin{array}{c}\text { Sepidan poultry } \\
\text { slaughterhouse wastewater } \\
\text { outlet }\end{array}$ & $\begin{array}{l}\text { Sewage outlet of Amirkola } \\
\text { Children's Hospital }\end{array}$ \\
\hline
\end{tabular}

\section{Phage Morphology Observation by Electron Microscopic}

For transmission electron microscopy (TEM) observation, the sample was prepared based on Brenner and Horne protocol (27). Briefly, the purified phage suspension $\left(10^{9} \mathrm{PFU} / \mathrm{mL}\right)$ was centrifuged at $15000 \times \mathrm{g}$ for $150 \mathrm{~min}$ and the supernatant was discarded. The pellet was washed with distilled water two times. The bacteriophage was deposited on a cuprum grid with carbon-coated formvar film and was stained with $2 \%$ potassium phosphotungstate $(\mathrm{pH}$ : 7.2) or $1 \%$ uranyl acetate $(\mathrm{pH}: 4.5)$. Following air drying, the sample was observed by TEM (ZEISS EM 900 , Germany) at an acceleration voltage of $50 \mathrm{kV}$. 


\section{SDS-PAGE Analysis of Phage Structural Proteins}

The purified phage suspension $\left(10^{9} \mathrm{PFU} / \mathrm{mL}\right)$ was centrifuged at $8000 \times \mathrm{g}$ for $60 \mathrm{~min}$ at $4^{\circ} \mathrm{C}$ (Centrifuge 5424 R, Eppendorf, Germany) and the supernatant was discarded. The phage pellet was suspended in 1 $\mathrm{mL}$ of loading buffer containing $2.5 \% \quad \beta$ mercaptoethanol, $2 \%$ SDS, $10 \%$ glycerol, and $0.0025 \%$ bromophenol blue in $6.25 \mathrm{~mm}$ Tris-HCL (pH: 6.8).

The suspension was heated at $100^{\circ} \mathrm{C}$ for $10 \mathrm{~min}$ to denature the phage proteins. Next, $14 \mu \mathrm{L}$ of denatured sample and $2 \mu \mathrm{L}$ of protein molecular weight marker (Thermo Fisher, Germany) were loaded in $12 \%$ polyacrylamide gel (PAGE) and were electrophoresed in 100-120 MV for $5 \mathrm{hr}$. Finally, after separation, dimension gels were stained with silver nitrate $(\mathbf{2 8}, \mathbf{2 9})$.

\section{Results}

\section{Plaques Formed by Isolated and Cultivated Phages}

Clinical isolates of MDR-K. pneumoniae and MDR-E. aerogenes were coded (Table 1) and used as host strains for isolating phages from the hospital, industrial, and urban wastewater of north of Iran. Three bacteriophages were isolated from the wastewater samples and a host bacterial strain for each bacteriophage was selected using the DLA technique. The bacteriophage produced clear plaques on the culture of the host bacterial strain (Figure 1).

Two lytic bacteriophages active against $K$. pneumoniae were isolated using the abovementioned strategy and were named as VB_Kp1, vB_Kp2. In addition, one lytic bacteriophage active against $E$. aerogenes was named as VB_Ea1 (Table 2). Afterwards, the clearest plaque of the three lytic bacteriophages was isolated, purified, and amplified. The titers of each phage lysate reached $109 \mathrm{PFU} / \mathrm{mL}$ or higher (Table 3 ).

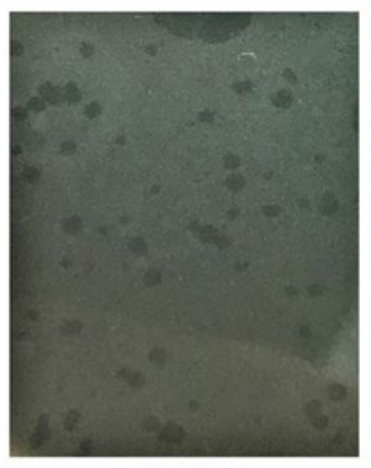

vB_Kp1

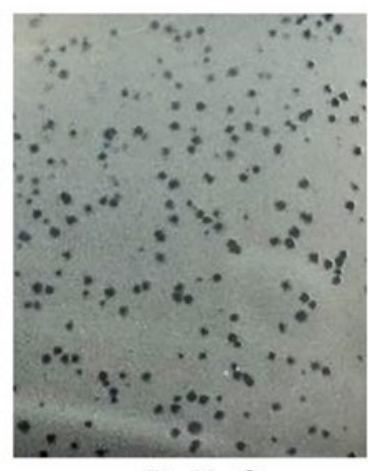

vB_Kp2

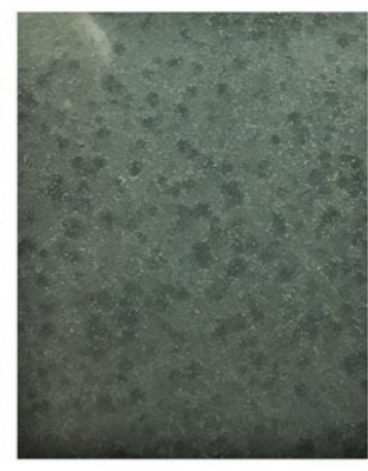

VB_Ea1

Figure 1. Primary plaques of three isolated phages

\section{Susceptibility of Isolated Strains to the Three Purified Phages}

The host range of the isolated phages (vB_Kp1, vB_Kp2, and vB_Ea1) was tested against 15 MDR- $K$. pneumoniae and 10 MDR-E. aerogenes clinically isolated strains and standard strains, including $P$. aeruginosa ATCC 1074, S. aureus ATCC 6538, E. coli ATCC 35218, S. typhi PTCC 1639, E. aerogenes PTCC 1221 , and K. pneumoniae PTCC 1290 . The spot assay method was employed to characterize host specificity in three different phages. Their infectivity was categorized based on plaque formation and in case the plaques were formed the strain was selected as a host of phage (Table 4).
As shown in Table 4, phages vB_Kp1 and vB_Kp2 lysed 5 (33.3\%) and 7 (46.6\%) samples out of 15 clinically isolated $K$. pneumoniae cases, respectively. Furthermore, vB_Ea1 was able to lyse 6 of 10 (60\%) clinical $E$. aerogenes samples. The phages could not infect 11 isolated MDR-strains, including $\mathrm{Kr} 1, \mathrm{Kr} 2, \mathrm{Kr} 5$, $\mathrm{Kr} 8, \mathrm{Kr}$, $\mathrm{Ka} 1, \mathrm{Ka} 4, \mathrm{Em} 2, \mathrm{Em} 5, \mathrm{Er}$, and Er4. The other isolated MDR-strains were sensitive to at least one of the isolated phages. The antibiotic resistance analysis of the susceptible strains revealed that all the strains were resistant to more than three of the tested antibiotics. 
Table 4. Susceptibilities of clinically isolated strains to infection with bacteriophages isolated from wastewater samples

\begin{tabular}{|c|c|c|c|}
\hline Strain & vB-Kp1 & vB-Kp2 & vB-Ea1 \\
\hline $\mathrm{Kr} 1$ & - & - & - \\
\hline $\mathrm{Kr} 2$ & - & - & - \\
\hline $\mathrm{Kr} 3$ & + & + & - \\
\hline $\mathrm{Kr} 4$ & - & + & - \\
\hline $\mathrm{Kr} 5$ & - & - & - \\
\hline Kr6 & + & + & - \\
\hline $\mathrm{Kr} 7$ & - & + & - \\
\hline Kr8 & - & - & - \\
\hline $\mathrm{Kr} 9$ & - & - & - \\
\hline Kr10 & + & + & - \\
\hline Kal & - & - & - \\
\hline $\mathrm{Ka} 2$ & + & + & - \\
\hline $\mathrm{Ka} 3$ & - & + & - \\
\hline $\mathrm{Ka} 4$ & - & - & - \\
\hline Ka5 & + & - & - \\
\hline Em1 & - & - & + \\
\hline Em2 & - & - & - \\
\hline Em3 & - & - & + \\
\hline Em4 & - & - & + \\
\hline Em5 & - & - & - \\
\hline Er1 & - & - & + \\
\hline Er2 & - & - & - \\
\hline Er3 & - & - & + \\
\hline Er4 & - & - & - \\
\hline Er5 & - & - & + \\
\hline E. aerogenes PTCC1221 & - & - & + \\
\hline K. pneumoniae PTCC 1290 & - & + & - \\
\hline P. aeruginosa ATCC 1074 & - & - & - \\
\hline S. aureus ATCC 6538 & - & - & - \\
\hline E. coli ATCC 35218 & + & + & - \\
\hline S. typhi PTCC 1639 & - & - & - \\
\hline
\end{tabular}

\section{Morphology of Lytic Bacteriophages}

The morphology of isolated and purified phages was analyzed using TEM (Figure 2). Phages had long tails of approximately 70, 80, and $110 \mathrm{~nm}$ in a noncompressed state. In various images prepared for each phage, the contracted and compressed tails could be observed. Moreover, phages vB_Kp1, vB_Kp2, and vB_Ea1 had icosahedral capsids measuring approximately 40,45 , and $70 \mathrm{~nm}$, respectively. The morphological characteristics of isolated phages as long contracted tail and icosahedral capsid are similar to those of the Mayoviridae family (Table 3 ).
Figure 2. TEM images of isolated phages (vB_Kp1, $v B \_K p 2$, and vB_Ea1); scale bars for each picture have been mentioned.

\section{Optimal Multiplicity of Infection}

Cultures of $10^{4} \mathrm{CFU} / \mathrm{ml}$ host bacteria in the early log phase $(O D=0.3)$ were infected with different amounts of designed phages and were evaluated to determine the phage titers after 2,4 , and $8 \mathrm{~h}$ of incubation. The optimal $\mathrm{MOI}$ was selected for subsequent experiments. The optimal MOls of vB_Kp1, vB_Kp2, and vB_Ea1 were $10^{3}, 10^{1}$, and $10^{3}$, respectively (Table 3). 

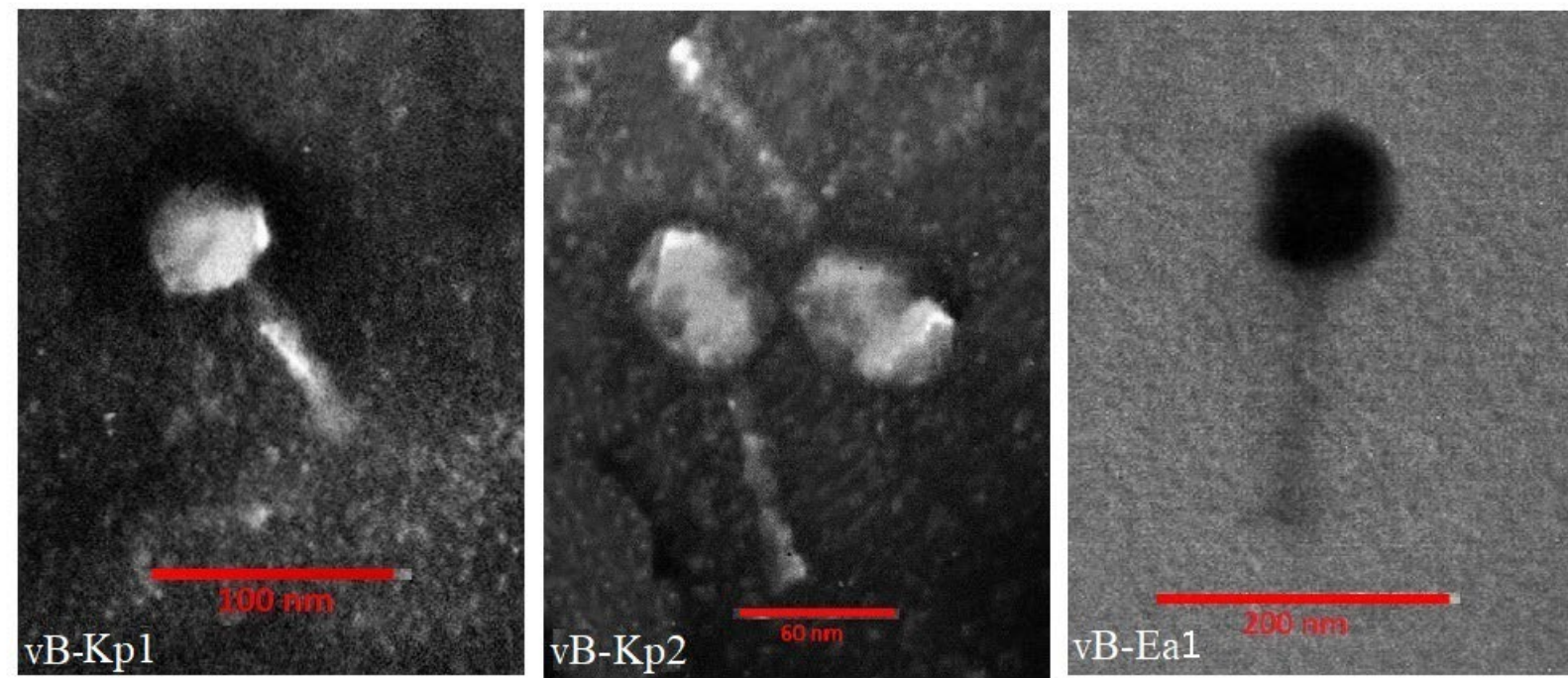

Figure 2. TEM images of isolated phages (vB_Kp1, vB_Kp2 and vB_Ea1). Scale bars for each picture have been mentioned.

\section{Latent Time and Isolated Phages Burst Size}

The one-step growth curve was represented to determine the latent time and burst size of each isolated and purified phage (Figure 3 ). Supported by the curves, the latent times of vB_Kp1, vB_Kp2, and
vB_Ea1, were found to be about 20, 10, and $10 \mathrm{~min}$, respectively. In addition, the burst sizes were 500, 833, and 333 PFU/infected cells, respectively (Table 3).

Figure 3. One-step growth curve of isolated bacteriophages vB_Kp1, vB_Kp2, and vB_Ea1.
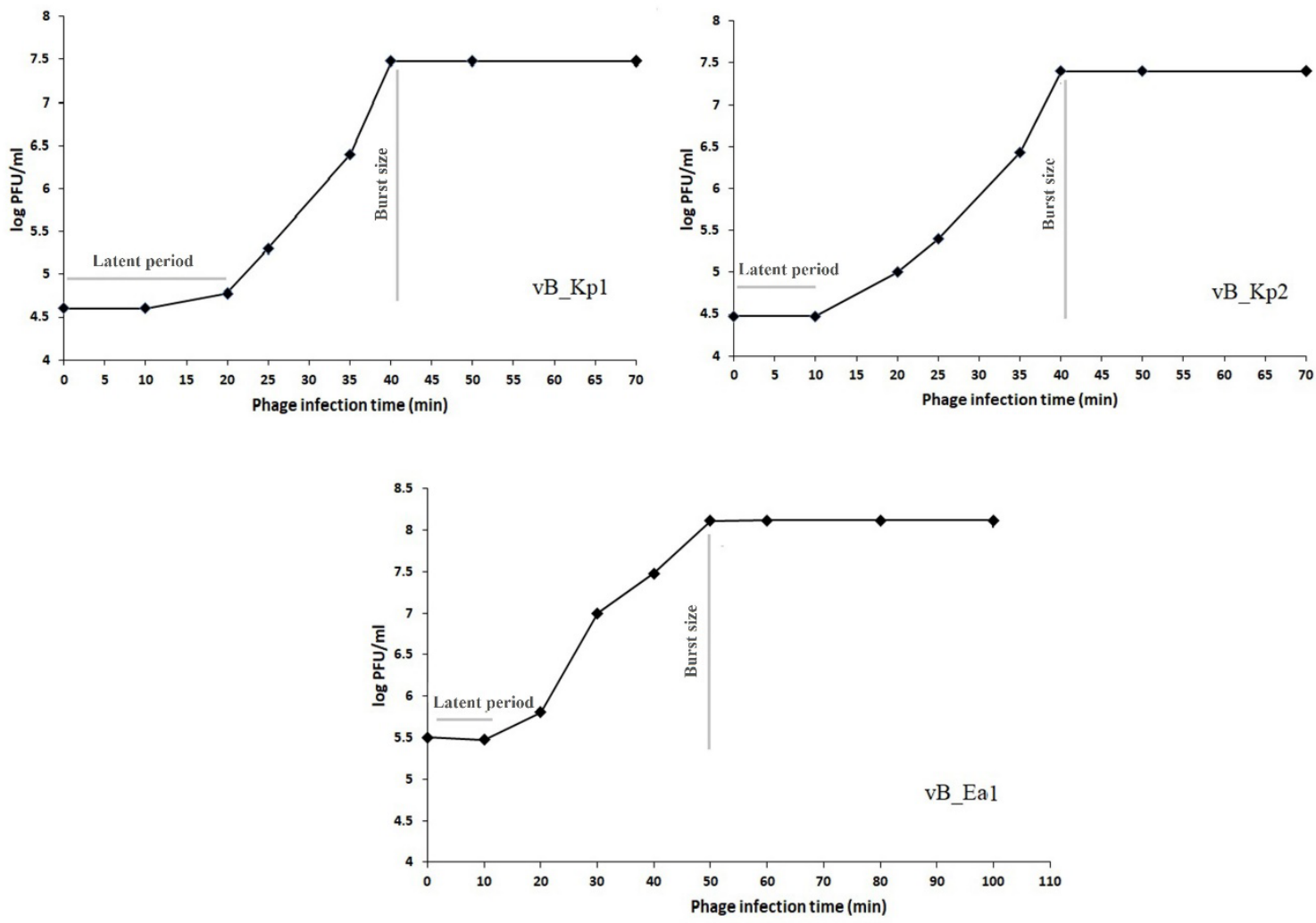

Figure 3. One-step growth curve of isolated bacteriophages vB_Kp1, vB_Kp2, and vB_Ea1. 


\section{SDS-PAGE Patterns of Structural Proteins of Isolated Phages}

Three isolated phages, namely vB_Kp1, vB_Kp2, and vB_Ea1 were analyzed in terms of their structural protein composition by SDS-PAGE. Many protein bands were observed in a silver-stained SDS polyacrylamide gel. All the three phages assigned to the Miroviridae family presented a different protein pattern in SDS polyacrylamide gel. Nevertheless, protein bands were observed with a size range of 18$70 \mathrm{kDa}$ (Figure 4). Several bands were observed to be very strong and some were weak in SDS polyacrylamide gel.

Figure 4. SDS-PAGE patterns of structural proteins of the isolated bacteriophages $\mathrm{VB} \_\mathrm{Kp} 1, \mathrm{VB} \_\mathrm{Kp} 2$, and vB_Ea1

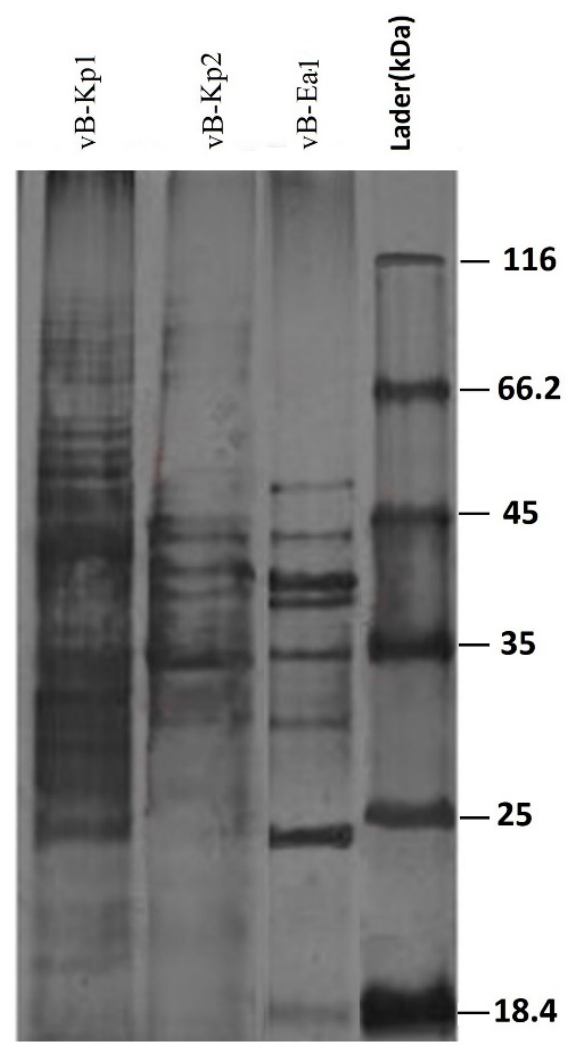

Figure 4. SDS-PAGE patterns of structural proteins of isolated bacteriophages vB_Kp1, vB_Kp2, and vB_Ea1.

\section{Discussion}

The rising incidence of gram-negative antibioticresistant bacterial infections, such as $E$. aerogenes and $K$. pneumoniae is one of the most remarkable problems in public health elevating the associated mortality rate and financial and psychological burden on patients and the healthcare system (30-34). $K$. pneumoniae and $E$. aerogenes have been identified as potently pathogenic organisms in various infections, which show an extraordinary ability to express ESBL,
KPC, and Metallo beta-lactamase making problems for successful treatment (4-7).

Therefore, for the treatment of MDR infections, efficient and affordable therapeutic approaches with fewer side effects are required. Lytic phages are similar to antibiotics in terms of significant antibacterial activity. However, therapeutic phages, at least in theory, have advantages over antibiotics. Phages have been reported to be much more effective and efficient than antibiotics in treating antibioticresistant infections in humans and laboratory animals.

In addition to being used to kill bacteria, phages have certain hosting properties that can be used to detect and type bacterial infections. Moreover, these products can provide an influential basis for phage therapy that requires rapid detection of bacterial targets and their sensitivity to specific phages.

Phage therapy is one of the significant, inexpensive, and specific methods that has attracted increasing attention for the treatment of MDR bacterial infections today $(35,36)$. However, new isolated MDR bacterial strains may be resistant to these phages. Bacteria can resist phage attack through diverse mechanisms, such as spontaneous mutations, restriction-modification systems, and adaptive immunity via the CRISPR-Cas system. Consequently, the identification of new phages and the creation of bacteriophage cocktails can be useful for improving therapeutic phages (37-39).

Up to now, many bacteriophages have been characterized as an antibacterial agent for $K$. pneumoniae $(40,41)$ and $E$. aerogenes $(42,43)$. In the present study, first, MDR-K. pneumoniae and MDR-E. aerogenes were isolated from clinical specimens and used as the main host to screen for bacteriophages extracted from hospital wastewater. Two phages, namely vB_Kp1 and vB_Kp2 against MDR-K. pneumoniae and $\mathrm{VB}$ Ea1 phage against MDR-E. aerogenes were isolated from hospital effluent.

Clear plaques are characteristic of lytic phages and all three isolated phages formed clear plaques showing their lysing potential. Electron microscopy showed that all the three phages isolated from the Myoviridae family are tail phages (44). The burst sizes of vB_Kp1, vB_Kp2, and vB_Ea1 are about 500, 833, and $333 \mathrm{PFU} /$ infected cells, and the latent times are about 20, 10, and $10 \mathrm{~min}$, respectively.

All three isolated bacteriophages showed several characteristics suitable for phage use, including forming clear plaques and having a short latent time and large burst size indicated by a one-step growth curve. Moreover, the SDS-PAGE patterns of structural proteins showed that all three isolated phages were similar to the protein patterns of other members of 
the Myoviridae family, such as Phaxl (45), $\varphi$ TMA (46), AP22 (25), and LP65 (47).

Karumidze et al. isolated bacteriophages VB-KLP-5 and VB-KLOX-2 from Georgia River wastewater. Clinical samples of $K$. pneumoniae and $K$. oxytoca were used to isolate and amplify phages. Both phages had large burst sizes and were stable under different adverse conditions. The phages reported in the current study are double-stranded DNA bacterial viruses belonging to families Podoviridae and Siphoviridae. The phages were able to lyse about $63 \%$ of the Klebsiella strains, including a set of 123 clinical isolates from Georgia and the United Kingdom. The properties of these phages indicated their potential to be applied in phage therapy cocktails (40).

In 2019, Zhao et al. identified a specific lytic bacteriophage for $E$. aerogenes isolates called VB_EaeM_фEap-3. Based on TEM analysis, phage vB_EaeM_фEap-3 was classified as a member of the Myoviridae family. Determination of host range demonstrated that vB_EaeM_ $\phi E a p-3$ was able to lyse 18 of the 28 strains of $E$. aerogenes while showing a one-step growth curve, short latent times, and a medium burst size. Considering host range, genome, and phage parameters, vB_EaeM_\$Eap-3 became a suitable candidate for phage therapy programs (42).

In the present study, phages vB_Kp1 and vB_Kp2 lysed about $33.3 \%$ and $46.6 \%$ of the clinical isolates of K. pneumonia. In addition, VB_Ea1 lysed approximately $60 \%$ of $E$. aerogenes isolates. These percentages indicate their applicability in phage therapy. Some studies have reported a wider host range for some phages.

For example, in the study performed by Komijani et al. over two years, K. pneumoniae was isolated from 193 infected wounds in three hospitals of Isfahan that were ESBL positive. The lytic phage was isolated against $K$. pneumoniae and the host range, morphology, thermal stability, $\mathrm{pH}$, salinity stress, and genome size were estimated. The phage was classified in the Myoviridae family due to the morphological characteristics. Out of 41 clinical specimens, 38 cases were phage sensitive (41). On the other hand, some other studies reported a very limited host range for isolated phages.
In a study by Li et al. in 2016, the phiEap-2 phage against $E$. aerogenes was isolated from wastewater and lysed $E$. aerogenes 3-sp strain. Following phage isolation, diverse properties, such as host range, phage structural proteins, genome structure and sequence, $\mathrm{pH}$ tolerance range, and resistance to different temperatures were investigated showing that this phage can be used for treatment (43).

Phages vB_Kp1, vB_Kp2, and VB_Ea1 could be suitable candidates for phage therapy research due to different characteristics, including short latent time, large burst size, and lyticity. However, further studies concerning resistance at different $\mathrm{pH}$ and temperatures, genomic sequencing, and bioinformatics studies are required.

\section{Conclusion}

Despite the findings of the present study, our data may not be sufficient for determining host specificity and phage type for successful therapeutic use. Therefore, further experiments, molecular analysis, complete genome sequencing, proteomics analysis, and clinical studies are necessary for selecting acceptable phage types against MDR-K. pneumoniae and MDR-E. aerogenes.

\section{Acknowledgment}

We would like to express our gratitude and thanks to all who helped during the implementation of this research. It is worth mentioning that this article is the result of a part of the dissertation of Ms. Fatemeh Habibi Nava from the Islamic Azad University, Qom Branch.

\section{Funding}

The financial resources of this research were provided by Ms. Habibi Nava

\section{Conflict of Interest}

The authors of the current study declared no conflict of interes. 


$$
\begin{aligned}
& \text { مجله ميكروبشناسى يزشكى ايران } \\
& \text { سال ها ـ شماره | ـ بهمن و اسفند 99"1 }
\end{aligned}
$$

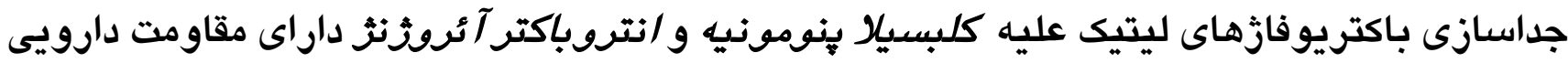

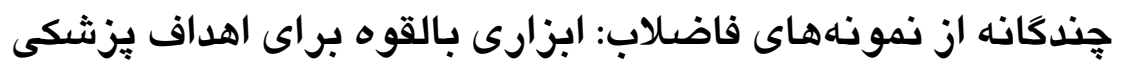

\author{
فاطمه حبيبى نوا'، محمدرضا ذوالفقارى ا“*، صالحه صبورى'، محسن زركر'، محمد سليمانى

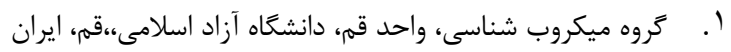

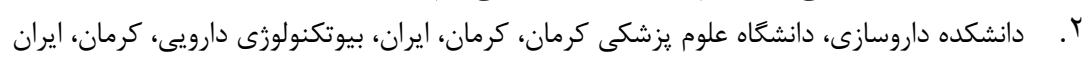

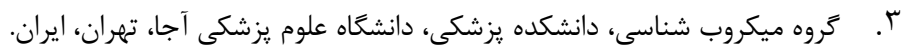

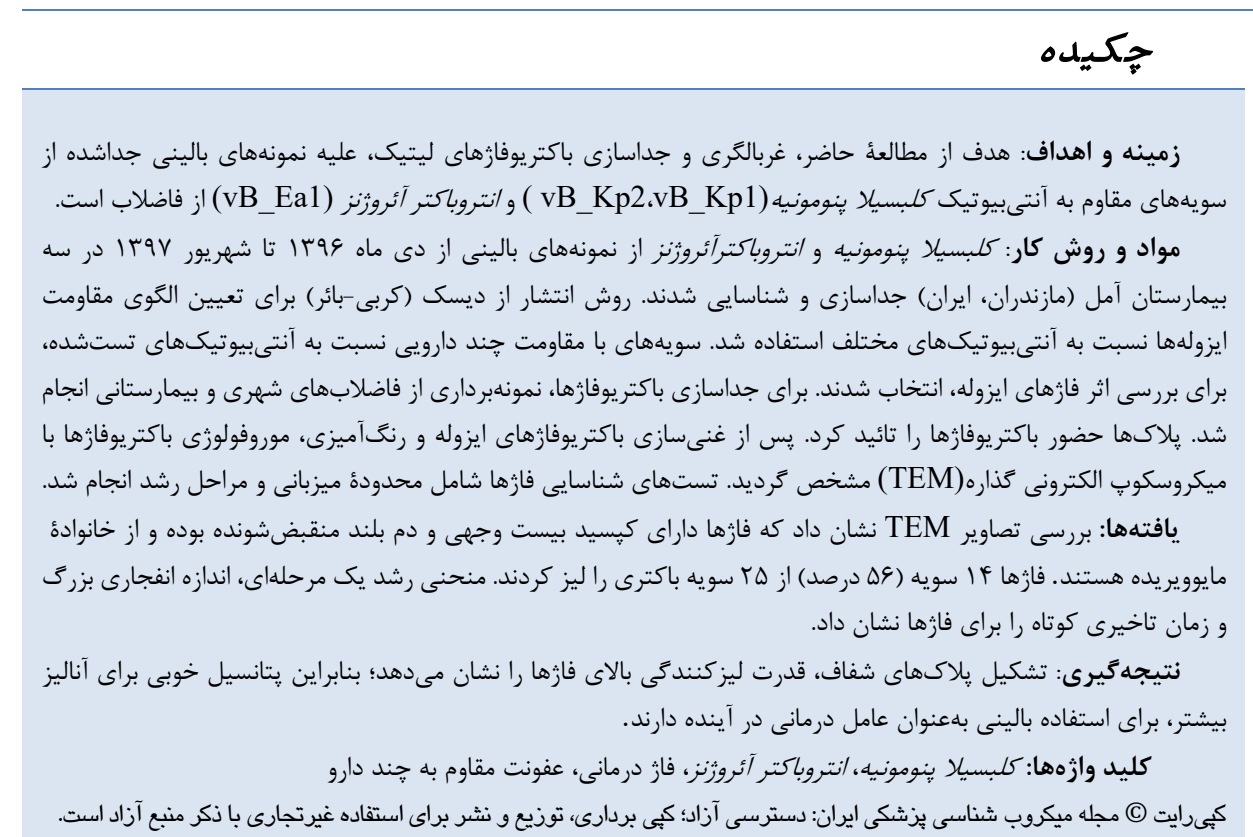

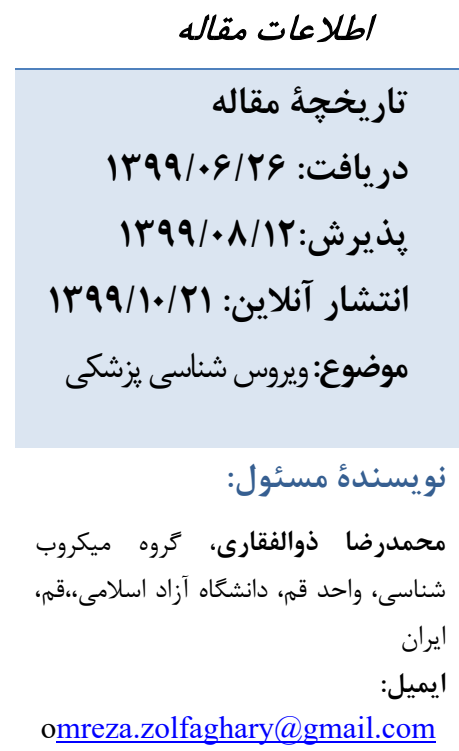

مقدمه

ينومونيه با بيان كاربإنماز (KPC)، بتا-لاكتاماز وسيعالطيف (ESBL) و

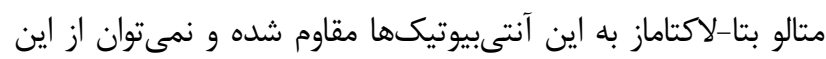

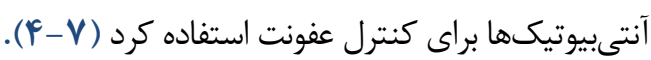
آلودگى با باكترىهاى گرم منفى مقاوم به جند دارو در افراد داراى سيستم ايمنى ضعيف، مانند نوزادان، افراد مسن، بيماران داراى نقص

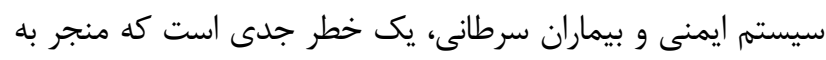

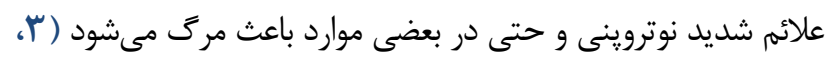
1). شيوع فزاينده عفونتهاى مقاوم به جند دارو، مشكلات درمانى و درمان طولانى مدت منجر به توليد داروهاى ضد باكترى جديد با بازده بالا با عوارض جانبى يايين و هزينهُ يايين براى درمان عفونتهاى مقاوم به جند دارو شده است.
يكى از مهمترين مشكلات بهداشت جهانى در دهأ اخير،

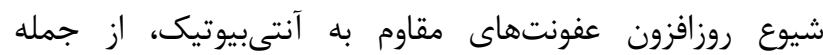
باكترىهاى گرممثبت و گرممنفى، بهويزه باكترىهاى "ESKAPE" شامل انتروكوكوس فاسيوم، استافيلوكوكوس اورئوس، كلبسيلا

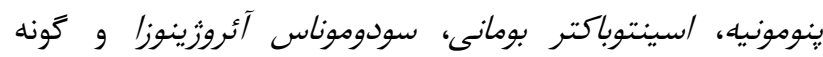

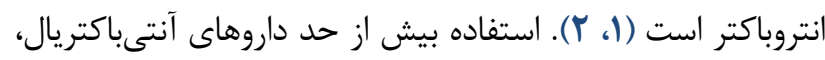
منجر به افزايش مقاومت به جند دارو و تغيير در جمعيت باكترى در اسر بيماران مىشود (ب).

باكترىهاى گرم منفى مانند/نتروباكترآئروزنز وكلبسيلا بنومونيه،

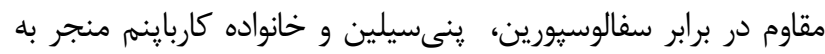
تشكيل عفونت مقاوم به جند دارو مىشوند. انتروباكتر آئروزنز وكلبسيلا 


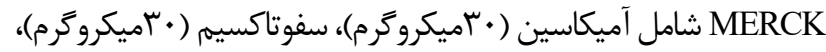

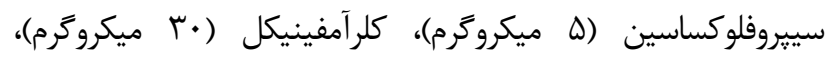

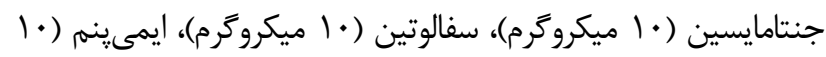

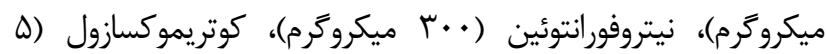

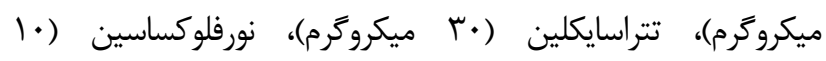

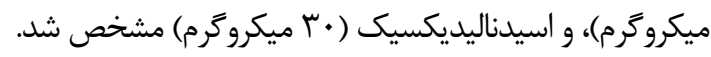
سويههايى كه حداقل به سه كلاس داروى ضد ميكروبى مقاوم هستند بهعنوان باكترىهاى مقاوم به جند دارو در نظر كرفته مى

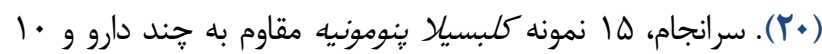

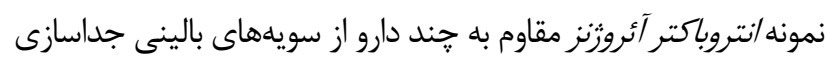

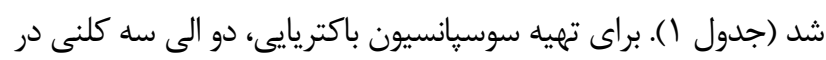

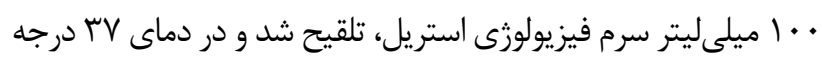
سلسيوس انكوبه شده تا كدورت سوسيانسيون باكترى، برابر با نيم

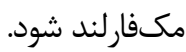

\section{جداسازى و تغليظ فاز}

نمونه فاضلاب بيمارستانى، صنعتى و شهرى از مكانهاى

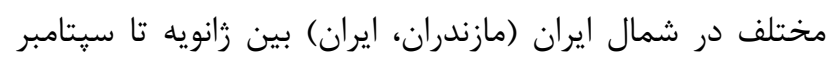

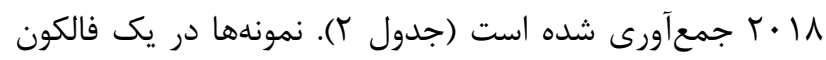

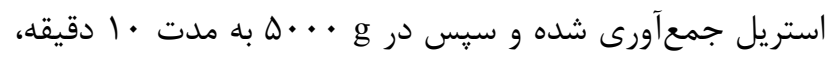

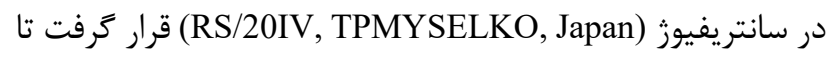
ذرات بزركتر جدا شوند. سويرناتانت بلهوسيلة فيلترهاى سرنكي

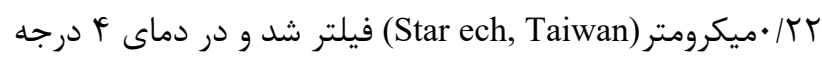
سلسيوس ذخيره شد.بهمنظور غنىسازى و تكثير باكتريوفاز،

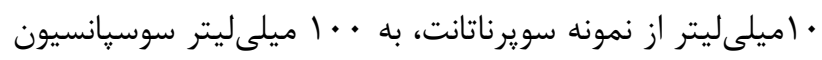

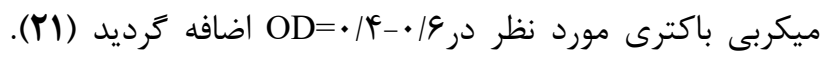

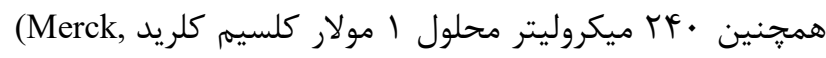

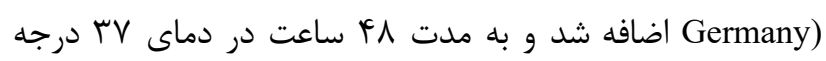

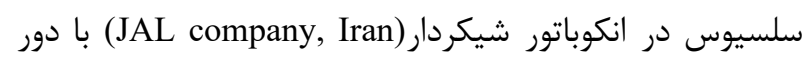

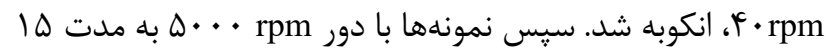

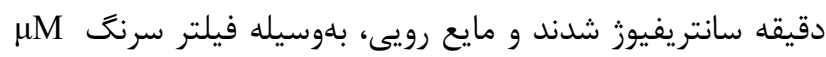

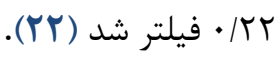

يكى از گزينههاى مورد علاقه در دو دهه اخير، ويروسهاى

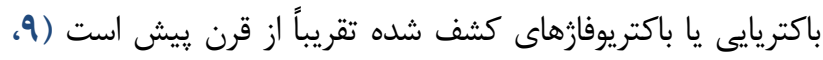

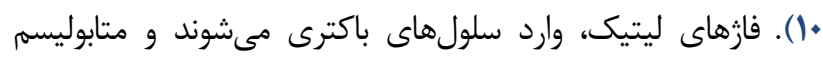

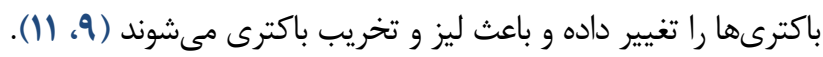

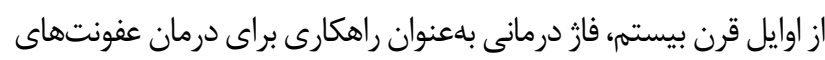

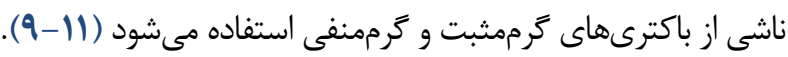

با توجه به مزاياى فاز درمانى، جندين كشور ارويايى و ايالات

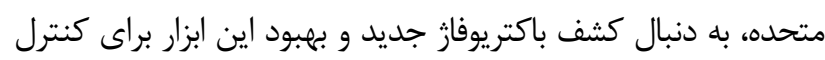

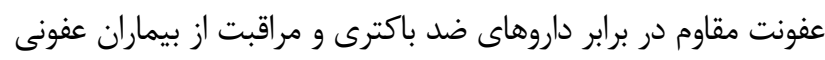

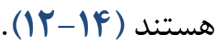

فاز درمانى علاوه بر اينكه در درمان عفونتهاى مقاوم به جند

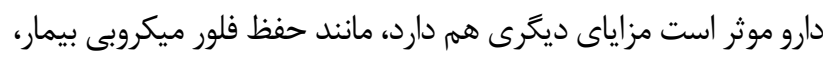

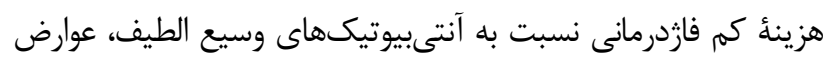

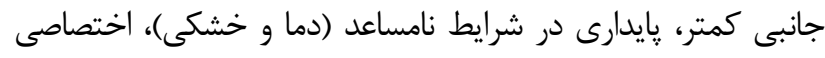

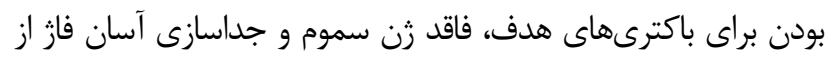

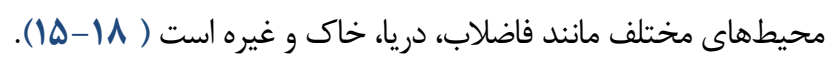
هدف از مطالعة حاضر، غربالكرى و جداسازى باكتريوفازهاى

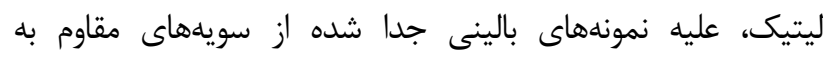
آنتىبيوتيك كلبسيلا بنومونيه وانتروباكتر آئروزنز از فاضلاب است إن.

$$
\text { مواد و روشها }
$$

\section{سويه هاى باكتريايى}

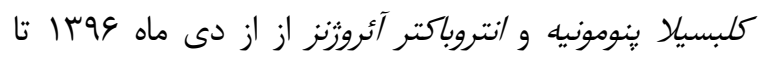

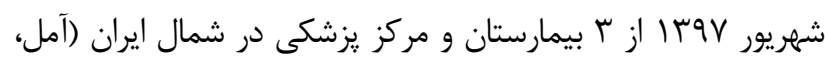

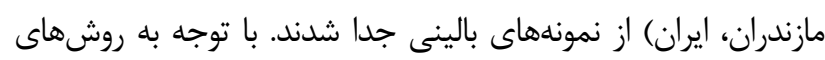

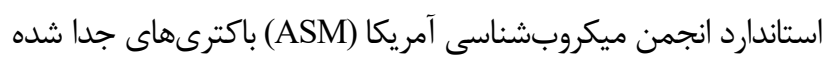

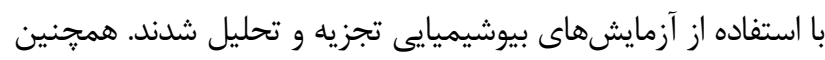

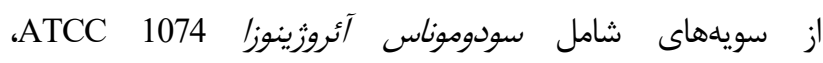

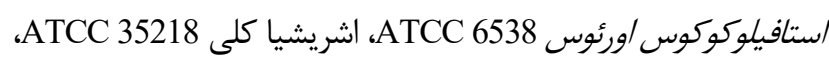

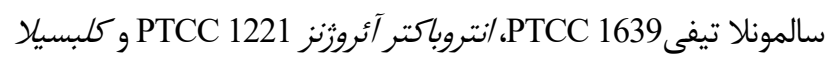
Pنومونيه PTCC 1290 استاندارد استفاده شد.

\section{تست حساسيت ضد ميكروبى}

الكوهاى حساسيت به آنتىبيوتيك با استفاده از روش فيك انتشار ديسك كربى-بائر روى محيط كشت مولر -هينتون آكار انجام شده است.

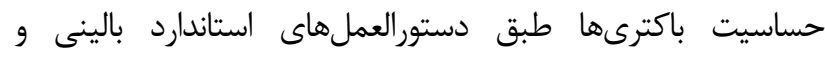

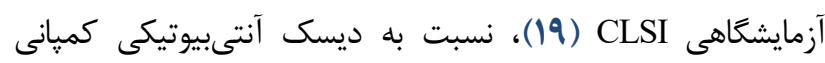


جدول ا. ايزولههاى كلينيكى كلبسيلا پِنومونيه و انتروباكتر آئروزنز مقاوم به جند دارو

\begin{tabular}{|c|c|c|c|c|}
\hline نشانه اختصارى & تعداد نمونه & منشا نمونه & منبع & ميكروار كانيسم \\
\hline $\begin{array}{c}\mathrm{Kr} 1 \\
\mathrm{Kr} 2 \\
\mathrm{Kr} 3 \\
\mathrm{Kr} 4 \\
\mathrm{Kr} 5 \\
\mathrm{Kr} 6 \\
\mathrm{Kr} 7 \\
\mathrm{Kr} 8 \\
\mathrm{Kr} 9 \\
\mathrm{Kr} 10\end{array}$ & 1. & 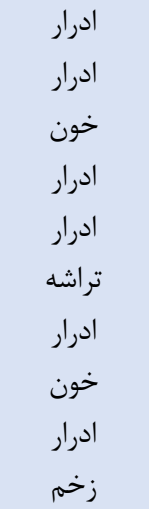 & $\begin{array}{c}\text { ايزوله بالينى بيمارستان } \\
\text { امام رضا آمل }\end{array}$ & كلبسيلا ينومونيه \\
\hline $\begin{array}{l}\mathrm{Ka} 1 \\
\mathrm{Ka} 2 \\
\mathrm{Ka} 3 \\
\mathrm{Ka} 4 \\
\mathrm{Ka} 5\end{array}$ & $\Delta$ & ز زخم زخم & $\begin{array}{c}\text { ايزوله بالينى بيمارستان } \\
\text { امام على آمل }\end{array}$ & كلبسيلا ينومونيه \\
\hline $\begin{array}{l}\text { Em1 } \\
\text { Em2 } \\
\text { Em3 } \\
\text { Em4 } \\
\text { Em5 }\end{array}$ & $\Delta$ & زادرار & ايزوله بالينى درمانگاه & انتروباكتر آثروزنز \\
\hline $\begin{array}{l}\text { Er1 } \\
\text { Er2 } \\
\text { Er3 } \\
\text { Er4 } \\
\text { Er5 }\end{array}$ & $\Delta$ & زادرار & $\begin{array}{c}\text { ايزوله بالينى بيمارستان } \\
\text { امام رضا آمل }\end{array}$ & انتروباكتر آثروزنز \\
\hline
\end{tabular}

جدول r. محل جمع آورى نمونههاى فاضلاب

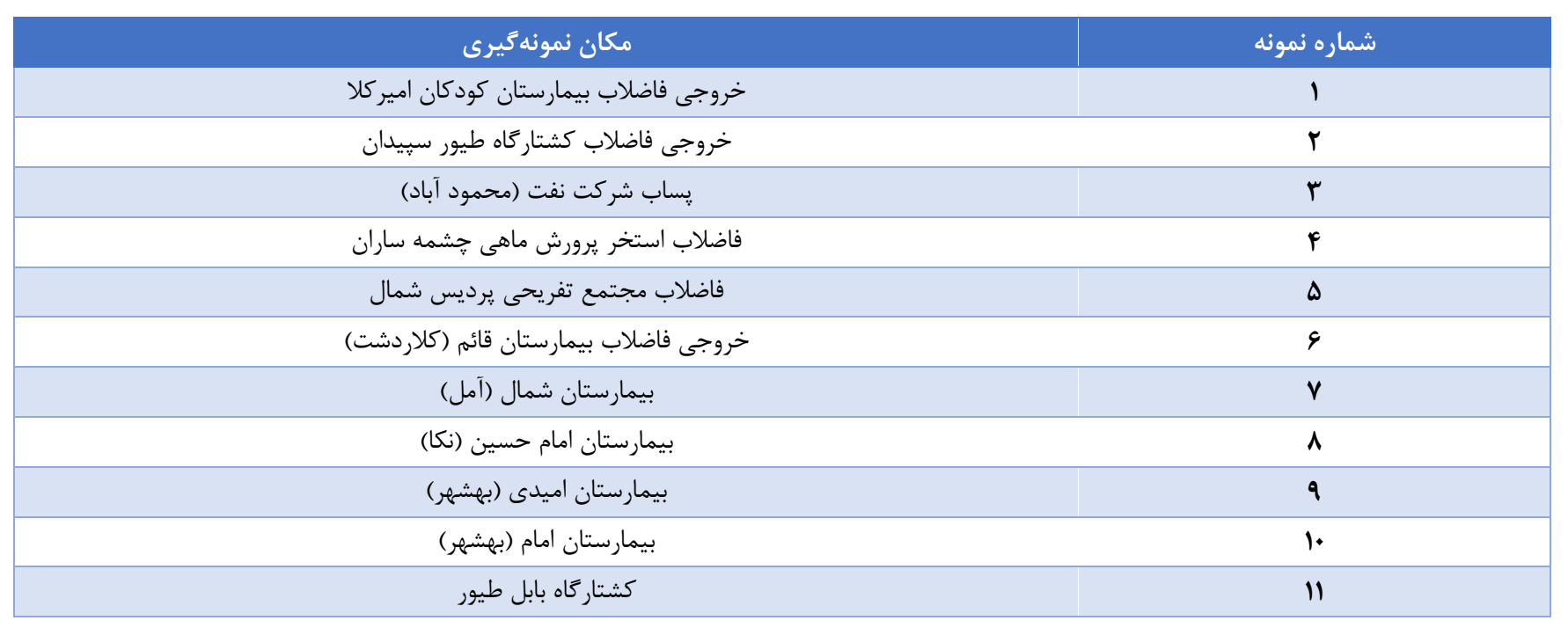


شدند. سيس از مايع رويى (فازهاى آزاد) رقت تهيه شده و با روش top agar overlay

\section{تعيين MOI بهينه}

بلمنظور بررسى اثر كشندگى فاز بر روى باكترى، لازم است تا بهينه نسبت فاز به باكترى (Multiplicity of infection) محاسبه شود (צץ). لذا داخل ميكرويليت و9 خانه، داخل هر خاهك،

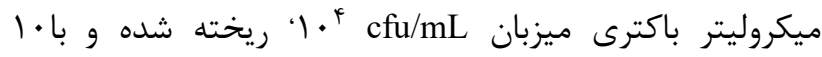

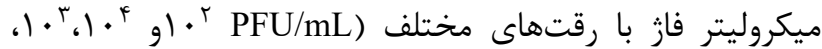

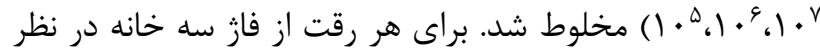

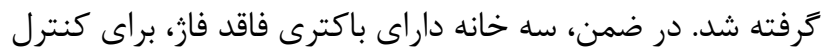
رشد باكترى و سه خانه داراى فاز فاقد باكترى، براى اطمينان از

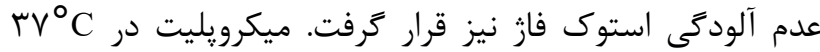

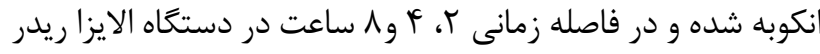
(ELX800, BioTek Instruments, USA)

\section{تعيين منحنى رشد يك مرحلهاى فاز}

باكترى ميزبان فاز مورد نظر، در mL • ا محيط كشت، تلقيح

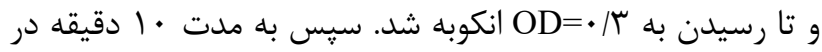

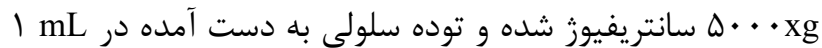
محيط كشت ريخته شد سيس طبق MOI بهينه فاز (جدول ؟)،

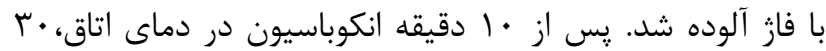

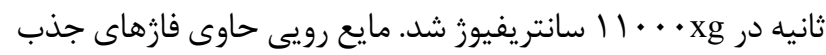
نشده، دور ريخته شده و سلولهاى آلوده شده موجود در رسوب،

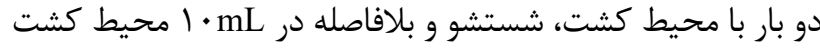

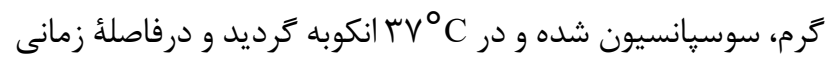
هر ده دقيقه، نمونهبردارى براى تعيين PFU انجام شد. نمونهها با

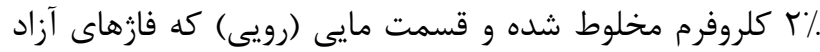
شده و داخل سلولى را نشان مىدهد، تيتر شد (YV).

\section{تهيه عكس با ميكروسكوب الكترونى گذاره يا عبورى}

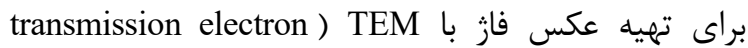

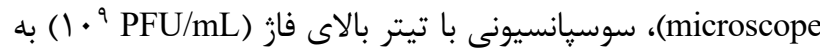

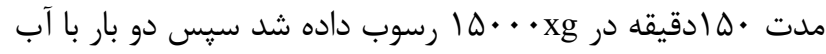

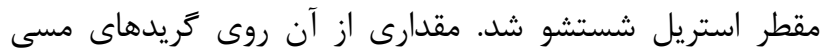

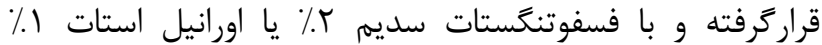

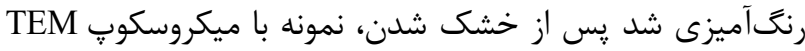

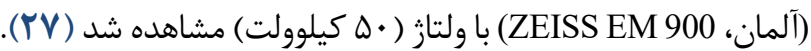

روش آكار دو لايه (Plaque Assay)

براى بررسى توانايى ضد باكترى فازهاى جدا شده، از روش

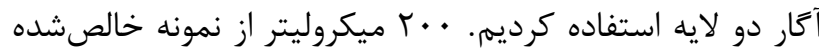

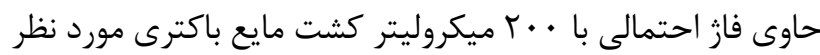

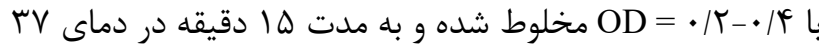
درجه سلسيوس به منظور جذب فاز به باكترى، گرمخانه كذارى

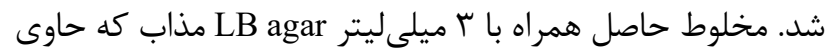

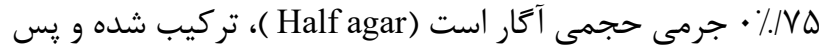

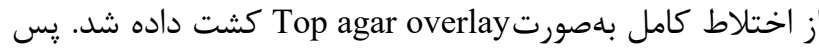

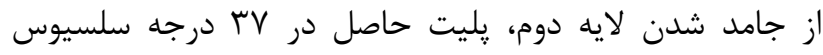

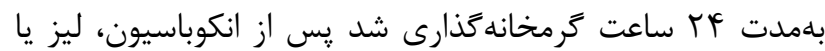

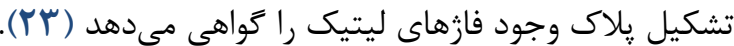

\section{خالصسازى فاز}

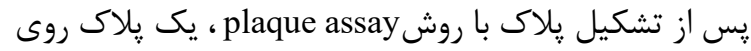

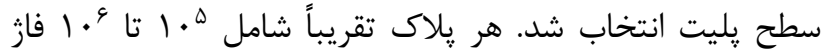

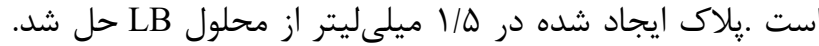

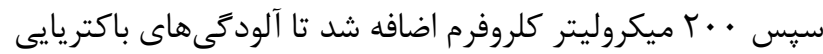
طبق روش بخش جداسازى فاز از بين برود .براى خالصسازى بهتر،

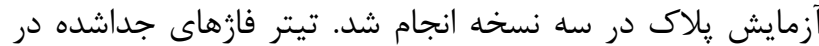
برابر باكترىهاى مقاوم به جند دارو از نمونههاى بالينى، بهصورت

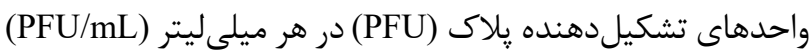
نشان داده شد كه توسط كارلسون و ميلر توصيف شده است (YF).

\section{تعيين محدوده ميزبانى}

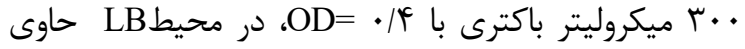

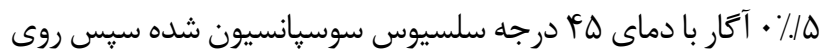
يك يليت حاوى LB آكار I ـا، قرار داده شد و قبل از بستن آكار، ده

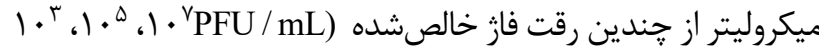

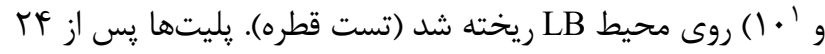
ساعت انكوباسيون در rV درجه، بر برسى و منطقه شفاف در ناحيه

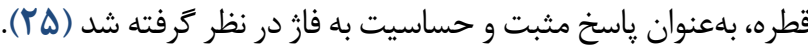

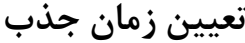

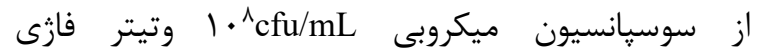
rV VYpfu/mL

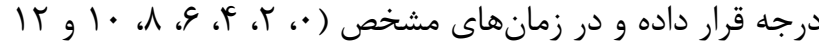

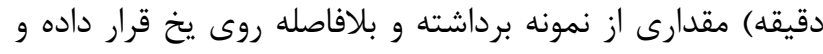

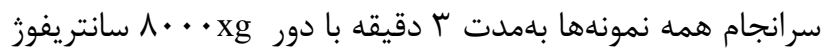


ليتيك، جداسازى، خالصسازى و غنىسازى شد و تيترهاى هر فاز

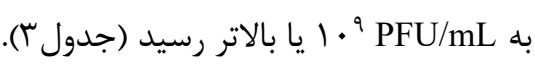

تعيين حساسيت سويههاى جدا شده كلبسيلا

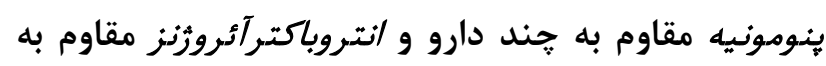
جند دارو به ب فاز خالص شده به

دامنه ميزبانى فازهاى جدا شده (vB_Kp2 ، vB_Kp1 )

ve_Ea1

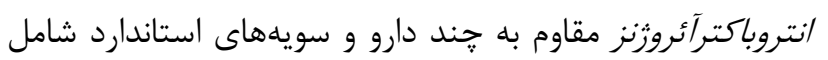

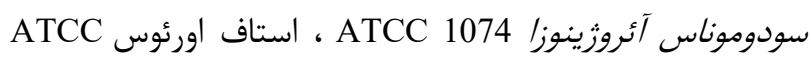

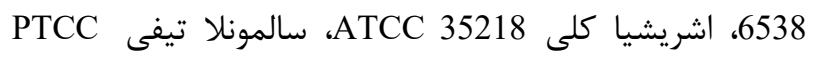

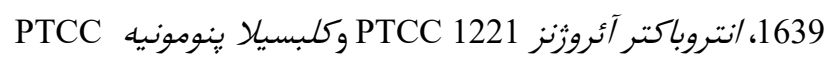

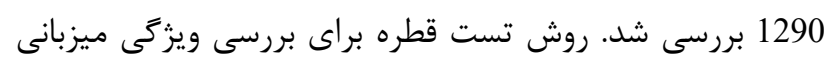

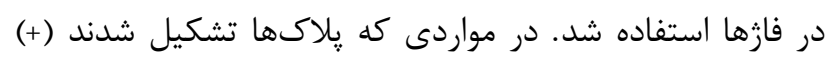

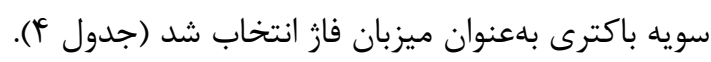

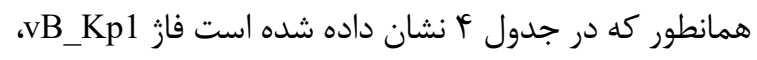

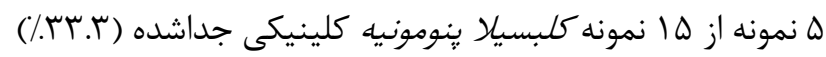

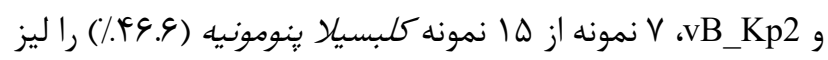

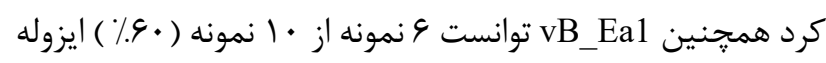

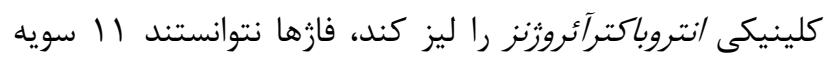

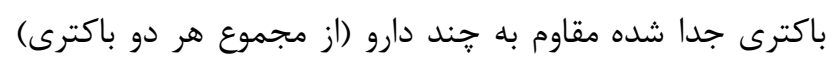

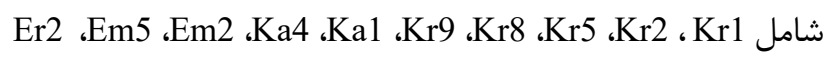



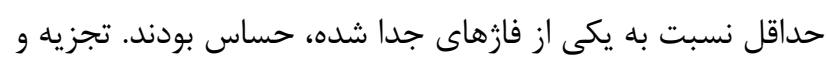

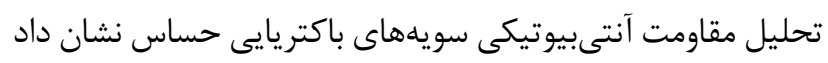

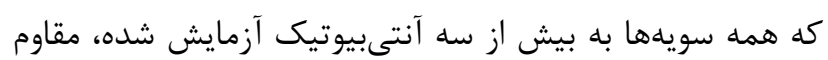

$$
\text { هستند. }
$$

\section{استخراج يروتئين و انجام SDS-PAGE} تيتر بالاى فاز (1) PFU/mL (centrifug5424 R, Eppendorf, ${ }^{\circ}$ rC سانتريفوز شد. رسوب حاصل در يك سىسى بافر (Germany)

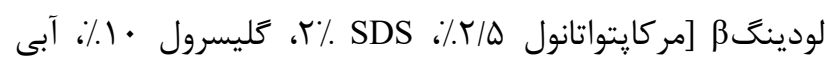

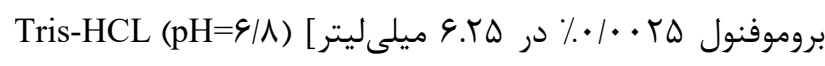

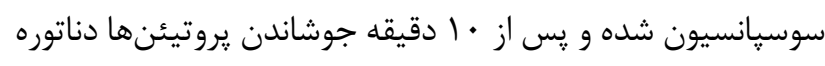

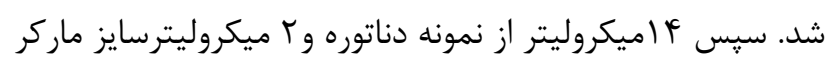

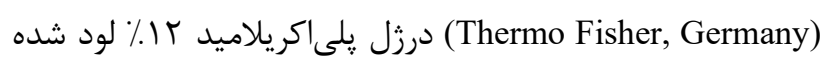

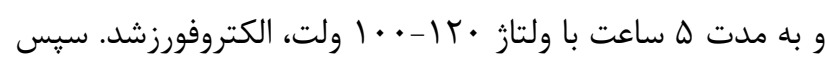

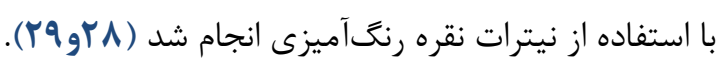

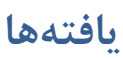

\section{تشكيل يلاك ها توسط فازهاى جداسازى شده}

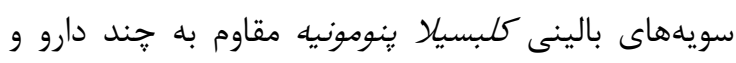

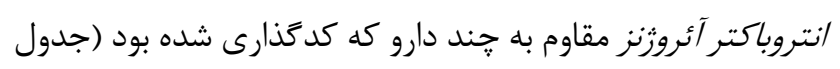



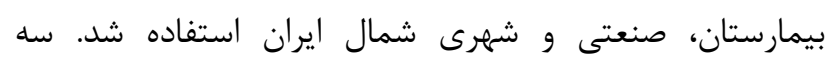

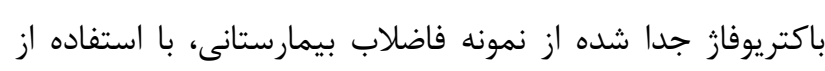

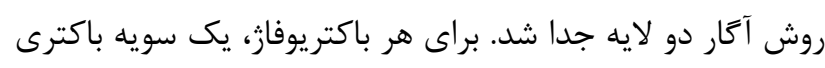

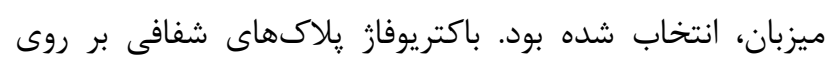

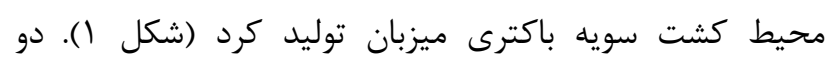

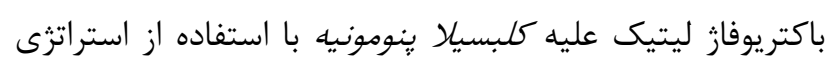

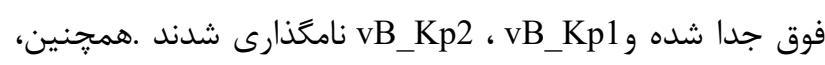

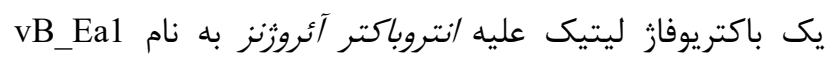

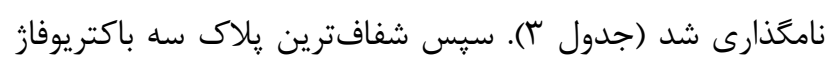

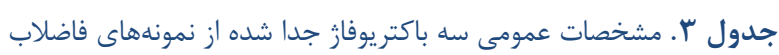

\begin{tabular}{|c|c|c|c|}
\hline 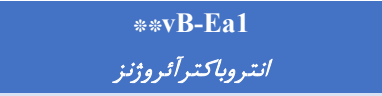 & $\begin{array}{c}\text { VB-Kp2 } \\
\text { كلبسيلا بنومونيه }\end{array}$ & $\begin{array}{c}\text { كلبسيلا بنومونيه } v \text { كB-Kp1 }\end{array}$ & باكترى ميزبان \\
\hline$r * 1 \cdot r$ & r*1."1 & $10 * 1.1$ & $\mathrm{PFU} / \mathrm{ml}$ \\
\hline شفاف & شفاف & شفاف & شكل يلاك \\
\hline $1 \cdot r$ & 1.1 & $1 . r$ & MOI \\
\hline 1. & 1. & $r \cdot$ & زمان تاخيرى (دقيقه) \\
\hline مايوويريده & مايوويريده & مايوويريده & خانواده \\
\hline v. & is & f. & قطر سر (نانومتر) \\
\hline 11. & $\wedge$. & $v \cdot$ & طول دم (نانومتر) \\
\hline خروجى فاضلاب بيمارستان كودكان اميركلا & خروجى فاضلاب كشتاركاه طيور & خروجى فاضلاب بيمارستان كودكان & 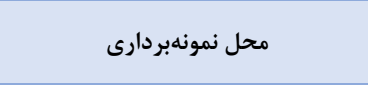 \\
\hline
\end{tabular}

\footnotetext{
* vB (bacterial virus), KP (K. pneumoniae), ${ }^{* *}$ vB (bacterial virus), Ea (E. aerogenes)
} 


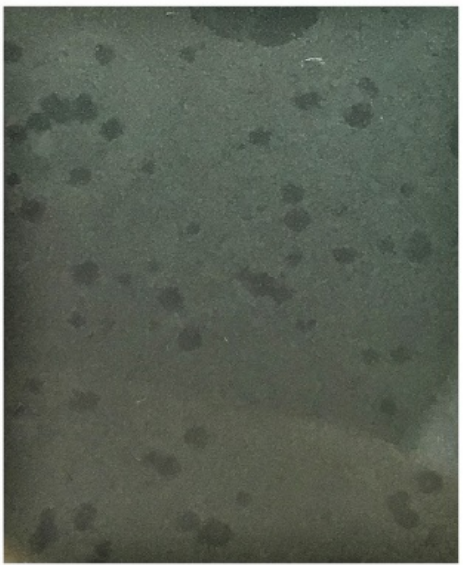

vB_Kp1

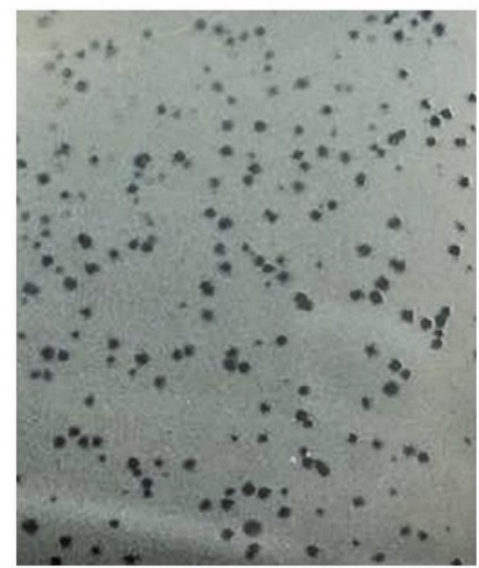

vB_Kp2

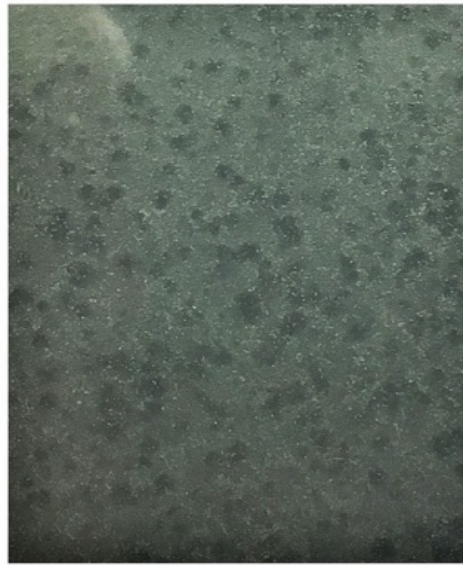

VB_Ea1

شكل ا. يلاكهاى اوليه ب فاز جدا شده

جدول F. حساسيت سويههاى بالينى ايزوله نسبت به عفونت با باكتريوفازهاى جدا شده از فاضلاب

\begin{tabular}{|c|c|c|c|}
\hline Strain & vB-Kp1 & vB-Kp2 & vB-Ea1 \\
\hline Kr1 & - & - & - \\
\hline $\mathrm{Kr} 2$ & - & - & - \\
\hline Kr3 & + & + & - \\
\hline Kr4 & - & + & - \\
\hline Kr5 & - & - & - \\
\hline Kr6 & + & + & - \\
\hline Kr7 & - & + & - \\
\hline Kr8 & - & - & - \\
\hline Kr9 & - & - & - \\
\hline Kr10 & + & + & - \\
\hline Ka1 & - & - & - \\
\hline Ka2 & + & + & - \\
\hline Ka3 & - & + & - \\
\hline Ka4 & - & - & - \\
\hline Ka5 & + & - & - \\
\hline Em1 & - & - & + \\
\hline Em2 & - & - & - \\
\hline Em3 & - & - & + \\
\hline Em4 & - & - & + \\
\hline Em5 & - & - & - \\
\hline Er1 & - & - & + \\
\hline Er2 & - & - & - \\
\hline Er3 & - & - & + \\
\hline Er4 & - & - & - \\
\hline Er5 & - & - & + \\
\hline انتروباكتر آثروزنز PTCC 1221 & - & - & + \\
\hline كلبسيلا ينومونيه PTCC 1290 & - & + & - \\
\hline سودوموناس أيروزينوز/ ATCC 1074 & - & - & - \\
\hline ATCC 6538 ستاف /ورئوس & - & - & - \\
\hline ATCC 35218 Aريشيا كلى & + & + & - \\
\hline سالمونلا تيفى 1639 PTCC & - & - & - \\
\hline
\end{tabular}

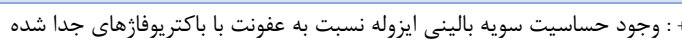

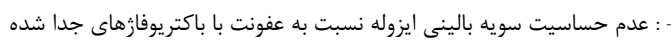



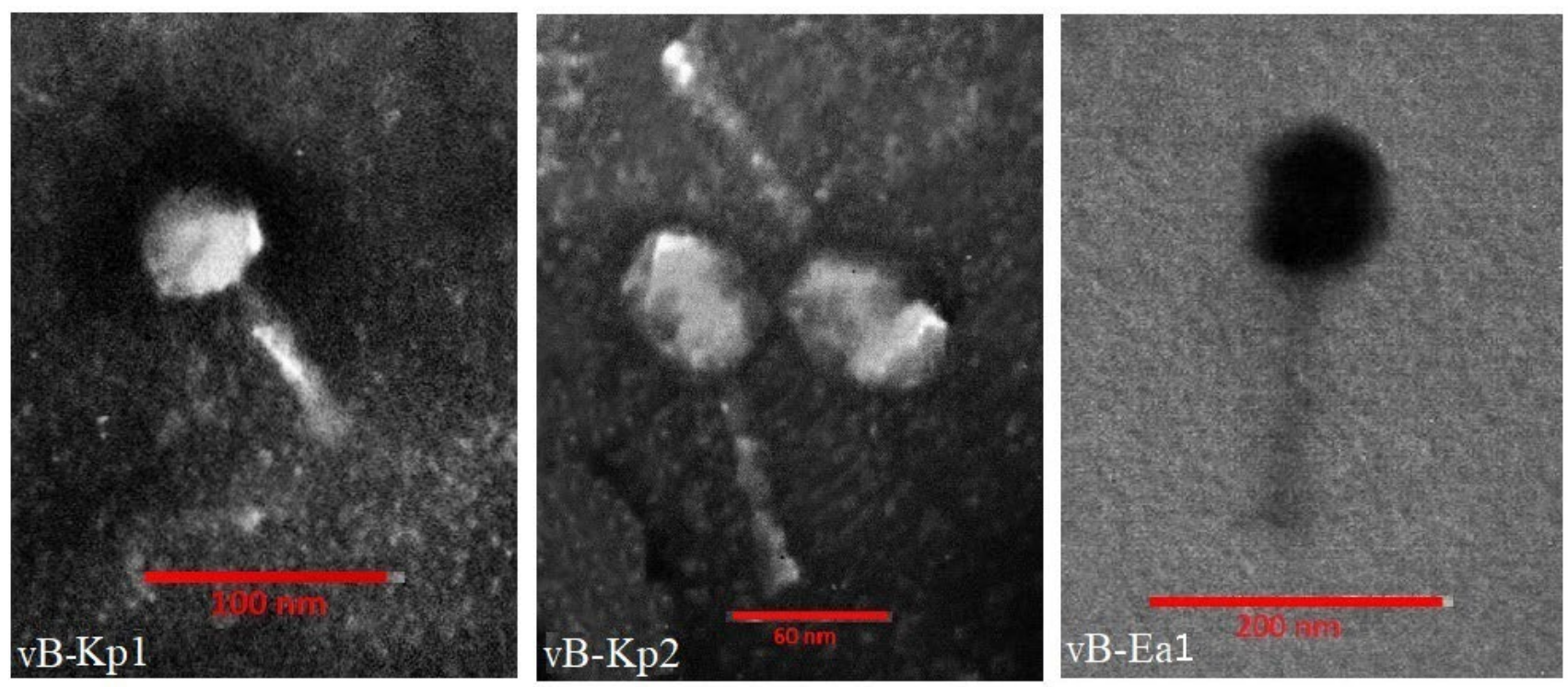

شكل r. تصاوير بدست آمده از TEM براى فارهاى جدا شده (vB_Ea1وvB_Kp2 ، vB_Kp1)

ساعت انكوباسيون، OD630 قرائت شد. MOI بهينه

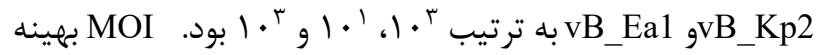

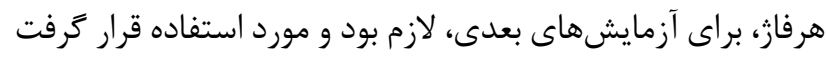

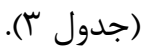

\section{زمان تاخيرى و اندازه انفجارى فازها}

منحنى رشد يك مرحلهاى براى تعيين زمان تاخيرى و اندازه

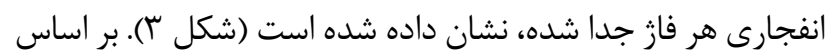
منحنىها، زمان نهفته vB_Kp2 ، vB_Kp1 و وvB_Ea1 ، حدود ·r، • ا و • ا دقيقه ارزيابى شد، در حالى كه اندازه انفجارى به ترتيب • • ه، سمر و سس ذره به ازاى هر سلول، مشخص شد

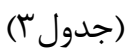

\section{مورفولوزى باكتريوفازهاى ليتيك}

مورفولوزى فازهاى جدا شده، با استفاده از TEM تجزيه و

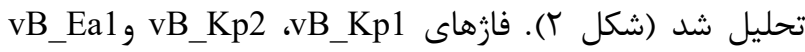

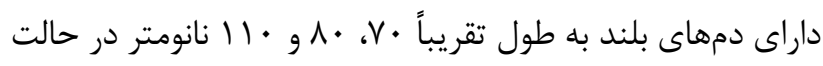

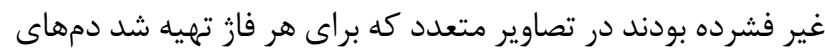
منقبض شده و فشرده هم ديده شد، همجنين فازها داراى كيسيد

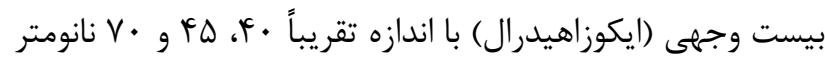
بودند. خصوصيات مورفولوزيكى فازهاى جداشده (دم بلند منقبض شونده وكيسيد بيست وجهى)، مشابه اعضاى خانواده مايوويريده

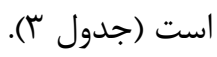

\section{تعيين MOI بهينه}

• 1 ميكروليتر باكترى ميزبان CFU/mL

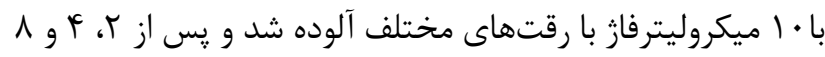



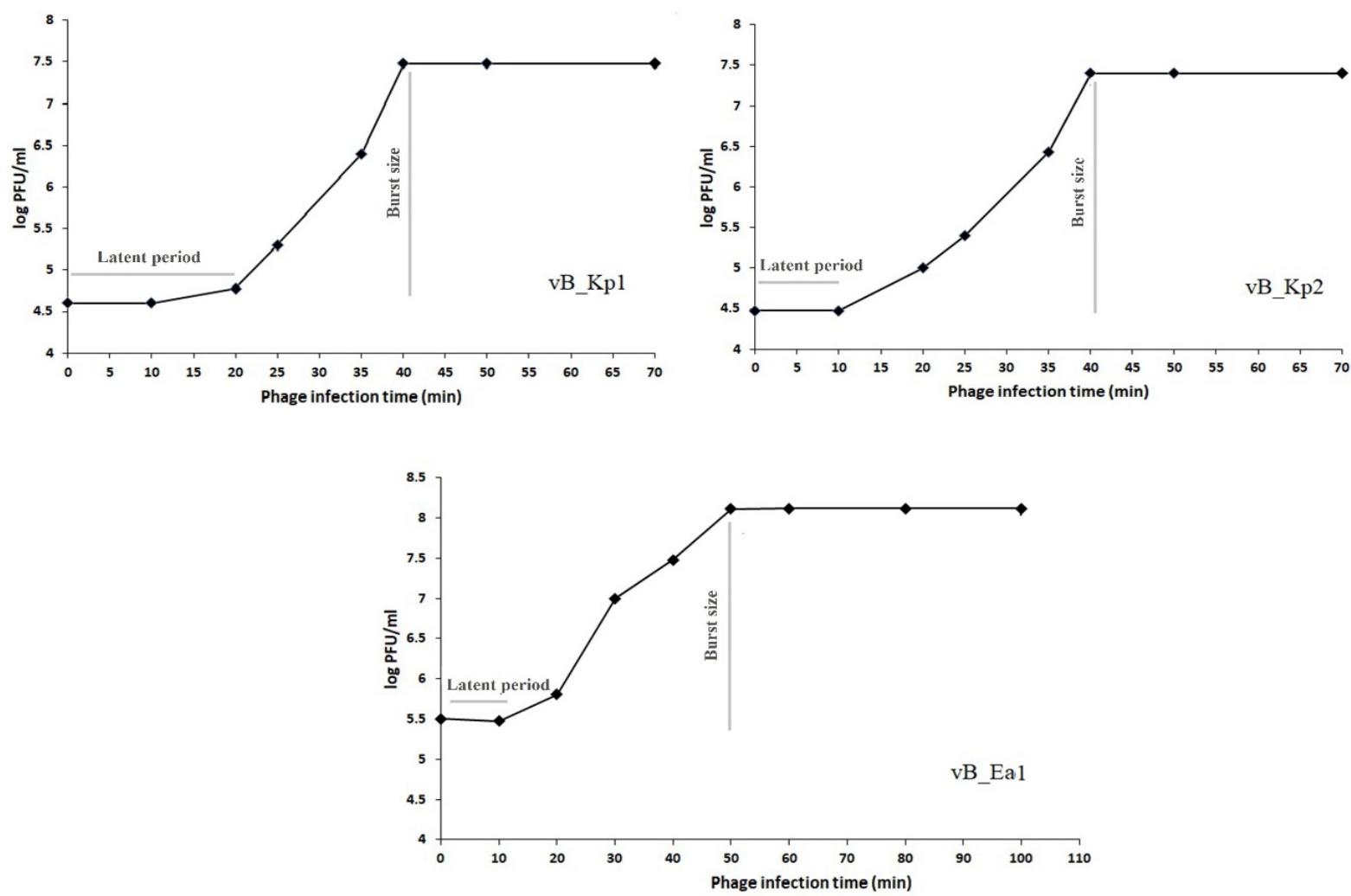

شكل rr. منحنى رشد يك مرحله اى باكتريوفازهاى جدا شده vB_Ea1,vB_Kp2 ، vB_Kp1.
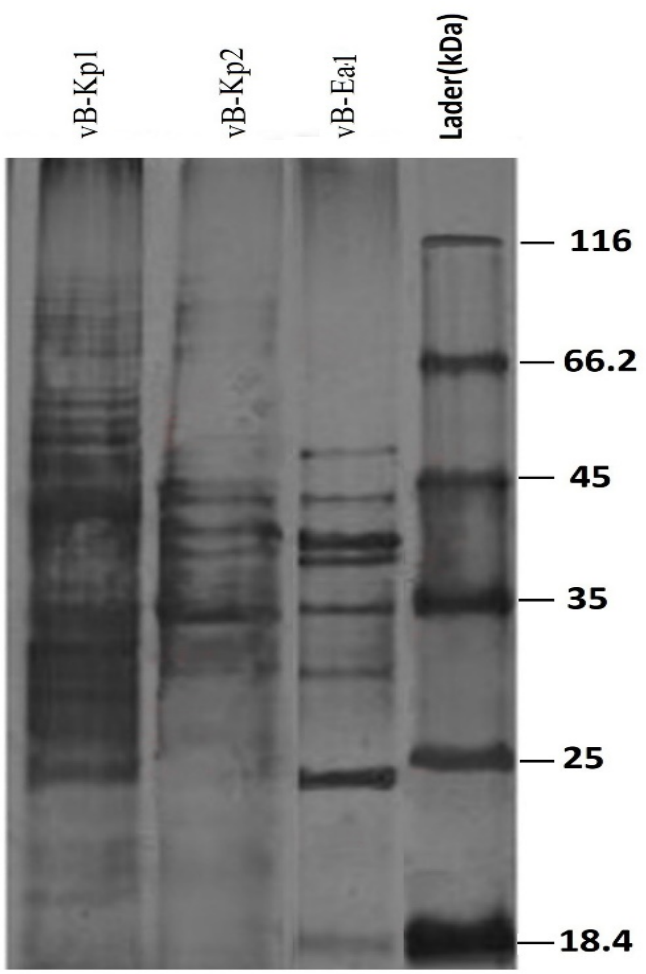

الخوهاى SDS-PAGE از يروتئينهاى ساختارى

فازهاى جدا شده

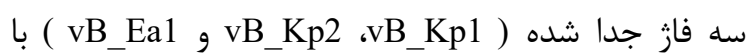
استفاده از SDS-PAGE براى تركيب تروتئين ساختارى مورد

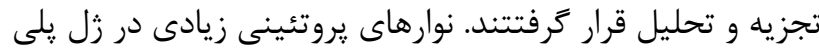

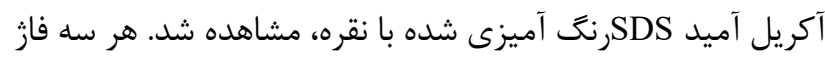

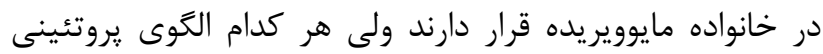

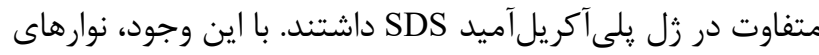

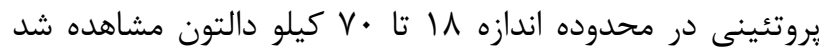

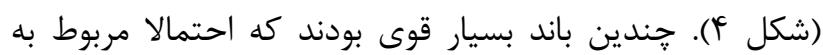

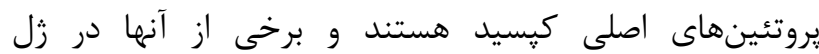

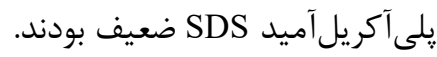

شكل ₹. الكَوهاى SDS-PAGE بروتئينهاى ساختارى

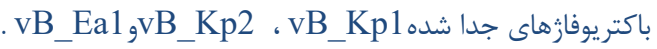


شده و بلهعنوان ميزبان اصلى در مطالعه حاضر براى غربالكرى

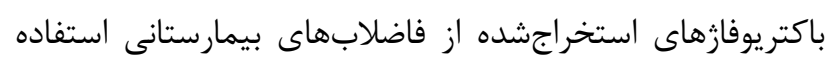

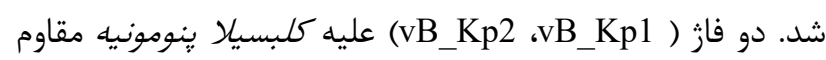

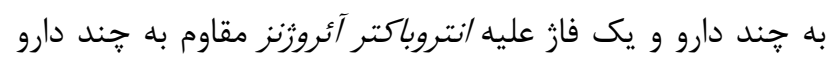

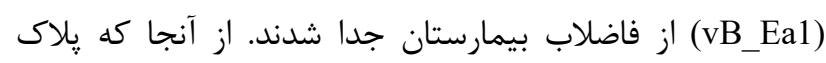

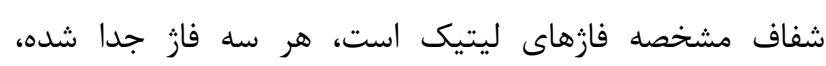

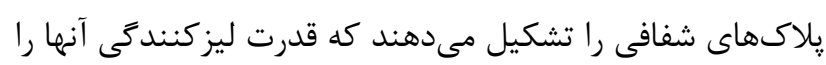

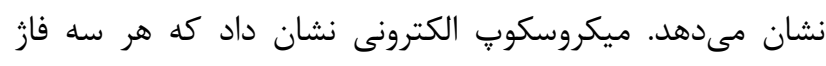

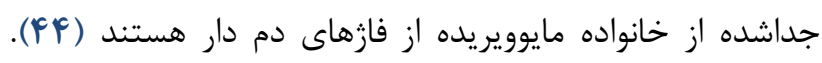

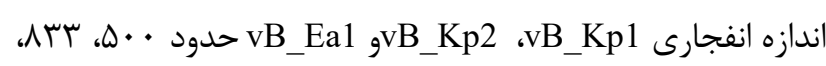

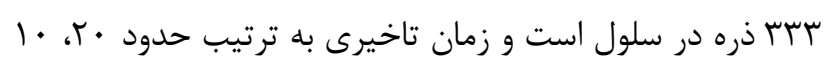

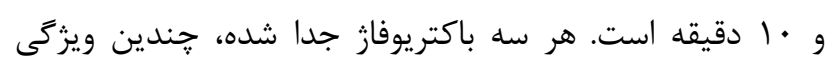



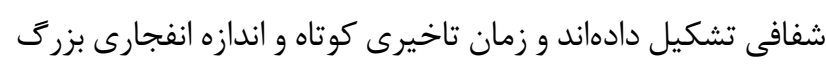

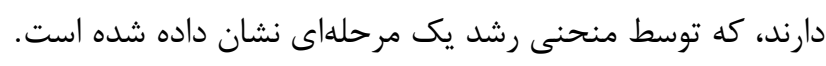

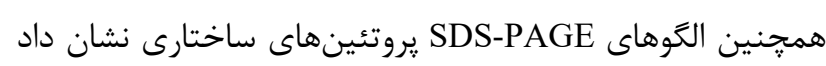

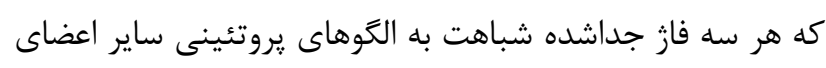
خانواده مايوويريده مانند (FA) LAP65 (FV) دارده LP22

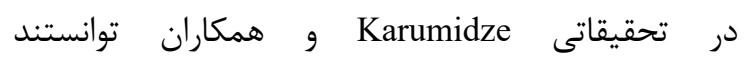
باكتريوفازليتيك الحقيقاتي

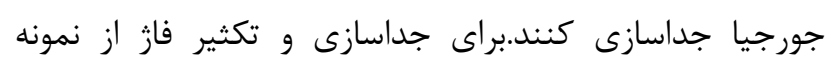
كلينيكى باكترىهاى كلبسيلا ينومونيه و كلبسيلا اكسى توكاري

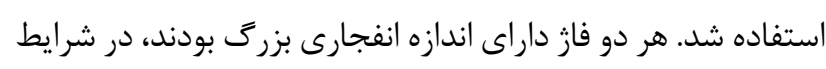

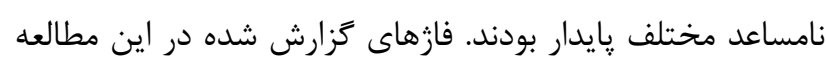

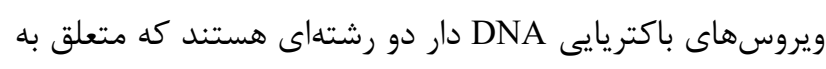

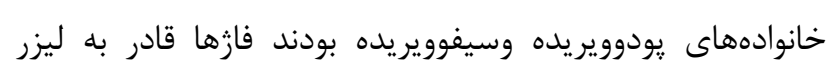



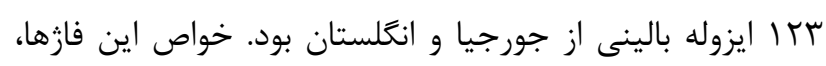

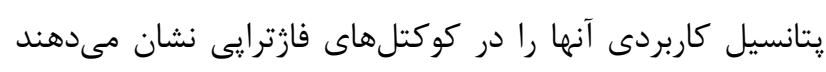

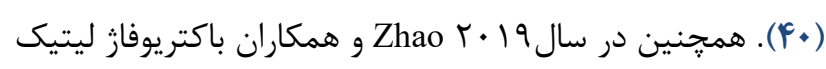

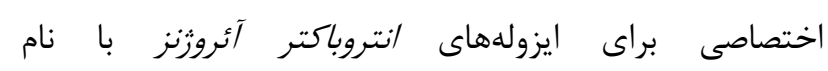
شناسايى شد. بر اساس تجزيه و تحليل vB_EaeM_pEap-3

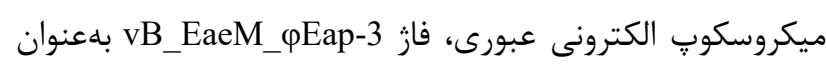

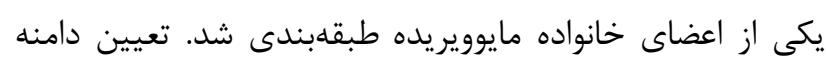

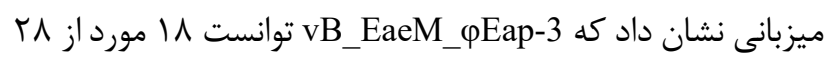

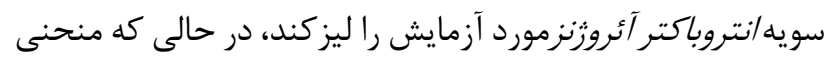

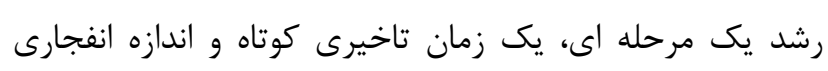

\section{بحث}

افزايش شيوع عفونتهاى مقاوم به آنتىبيوتيك باكترىهاى

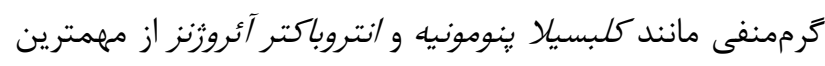

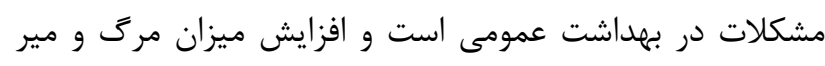

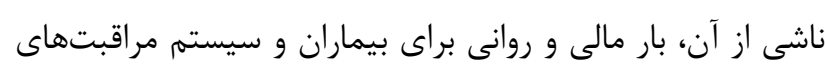

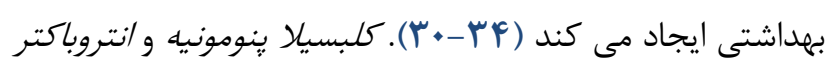

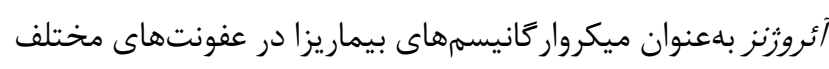

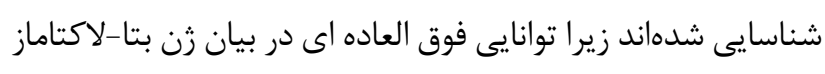

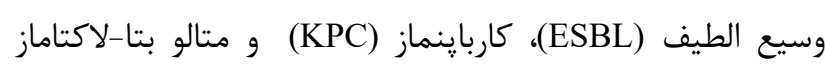

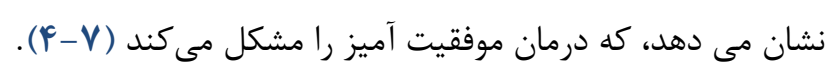
بنابر اين، براى درمان عفونت مقاوم به جند دارو، رويكردهاى

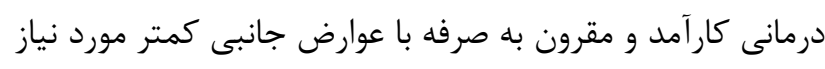

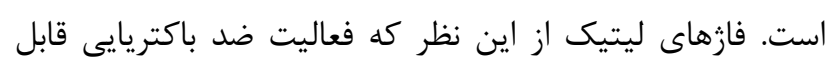

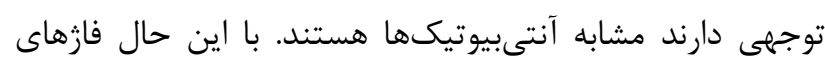

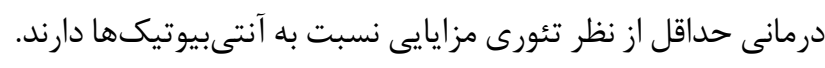

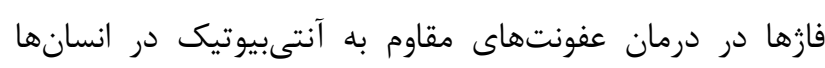

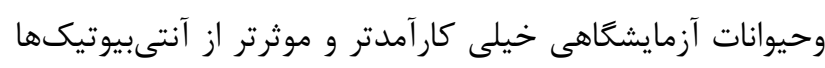

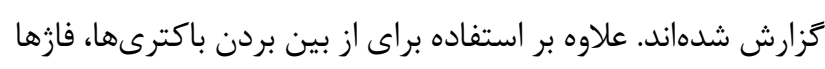

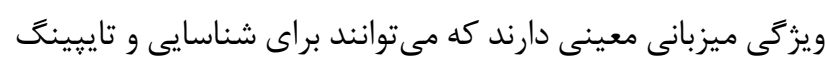

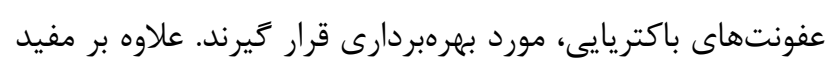
بودن بهعنوان تشخيص عمومى، اين محصولات ميى بوتوانند زمينه

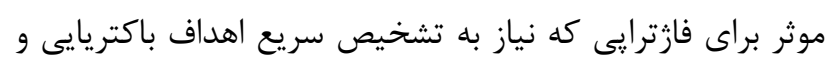

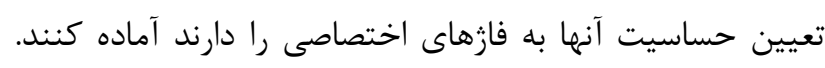

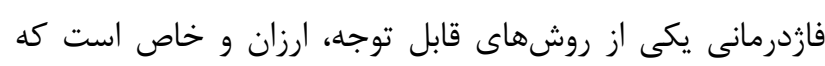

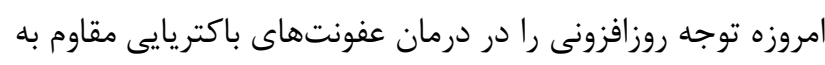

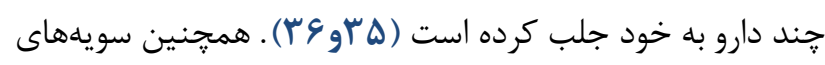

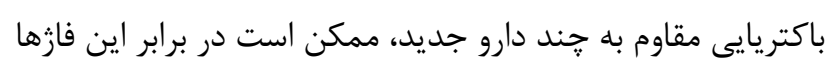

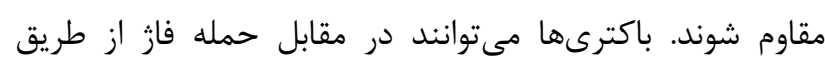

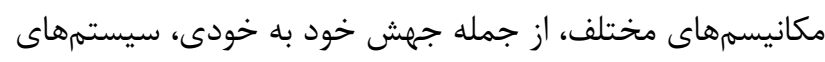
restriction modification CRISPR-Cas

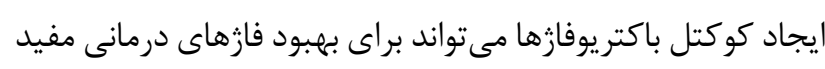

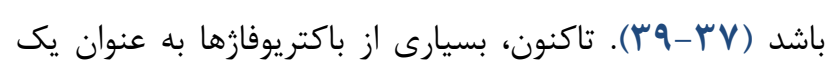

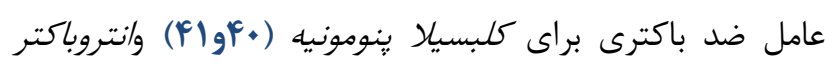

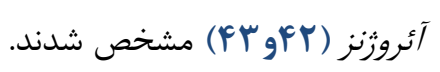

در مطالعه حاضر در ابتدا كلبسيلا ينومونيه مقاوم به جند

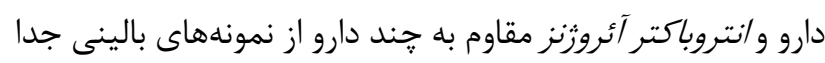


بررسى مقاومت در pH و دماهاى مختلف، بررسى توالى زنومى و بررسى هاى بيوانفورماتيك است. نتيجها كيرى

با وجود يافتههاى اين مطالعه، ممكن است دادههاى ما براى

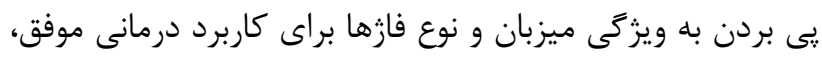

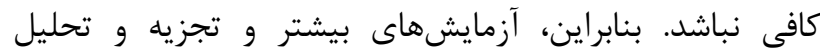

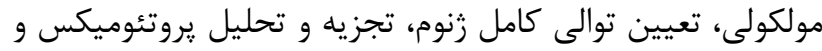

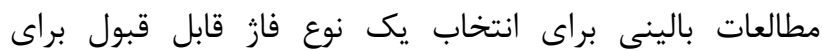
فازدرمانى، ضرورى به نظر مىرسد. در نتيجه، مطالعه ما نشان داد

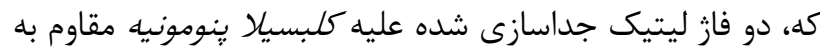

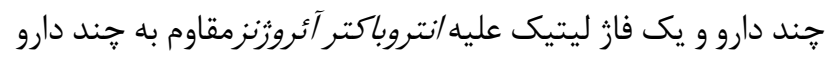
با وجود ويزگى هاى مناسب، كانديداى خوبى براى استفاده بهعنوان

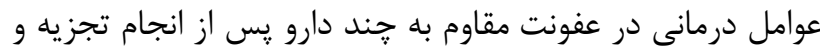
تحليلهاى بيشتر هستند.

\section{سياسگَزارى}

بدين وسيله مراتب قدرانى و تشكر خود را از تمام كسانى كه در طول اجراى اين يروهش مرا يارى كردند اعلام مىنمايم. شايان ذكر است كه اين مقاله حاصل بخشى از يايان إنامه دكترى خانم فاطمه حبيبى نوا از دانشكاه آزاد اسلامى واحد قمى است.

$$
\text { تعارض در منافع }
$$

درانجام مطالعُ حاضر، نويسندكان هيجّكونه تضاد منافعى

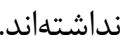

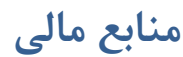

منابع مالى اين تحقيق توسط، خانم حبيبى نوا تامين شده است.

\section{Referance}

1. Pendleton JN, Gorman SP, Gilmore BF. Clinical relevance of the ESKAPE pathogens. Expert Rev Anti Infect Ther. 2013;11(3):297-308. [DOI:10.1586/eri.13.12] [PMID]

2. Ventola CL. The antibiotic resistance crisis: part 1: causes and threats. Pharmacol Therapeut. 2015;40(4):277.

3. Van Duin D, Paterson DL. Multidrug-resistant bacteria in the community: trends and lessons learned. Infect Dis Clin. 2016;30(2):377-90. [DOI:10.1016/j.idc.2016.02.004] [PMID] [PMCID]
متوسط را نشان مىدهد. با توجه به محدوده ميزبان، رنومى و

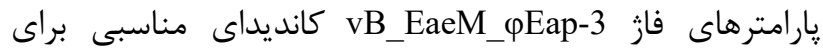

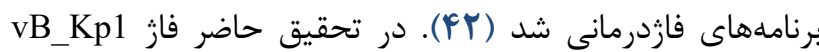

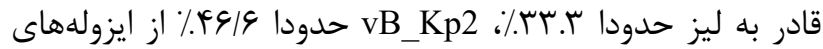

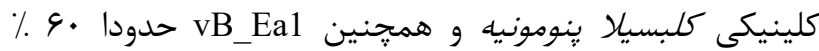

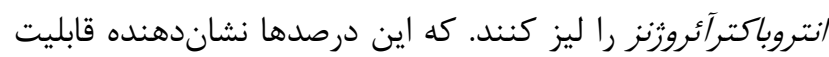

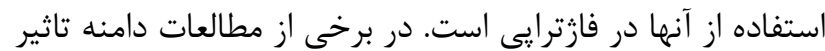

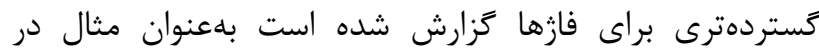
مطالعهاى Komijani در يك دوره دو ساله، سويه كلبسيلا بنومونيه

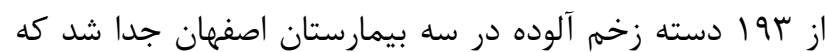
ESBL

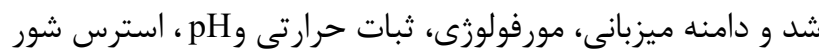

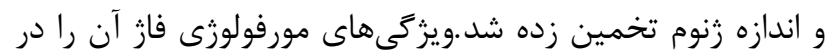

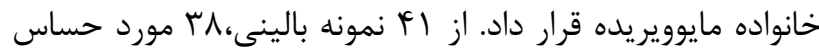
به فاز بودند (F) . از سوى ديكر برخى مطالعات ديكر دامنه ميزبانى

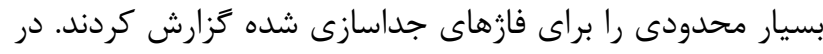

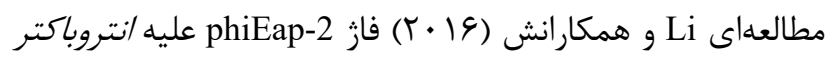

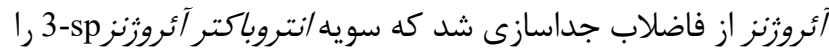
ليز كرد. يس از جداسازى فاز خصوصيات آن از جمله محدودئ

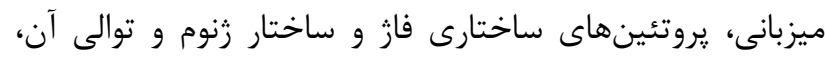

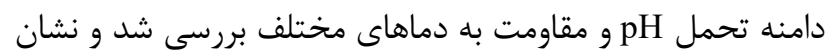
داد كه اين فاز مىتواند براى درمان استفاده شود (FT). با توجه به ساير خصوصيات فازهاى vB_Kp1، vB_Kp2


همجنين ليتيك بودن آنها مىتوانند كانديداى خوبى براى تحقيقات فازدرمانى باشند اما نياز به مطالعات ديكرى همجون

4. Rawat D, Nair D. Extended-spectrum $\beta$-lactamases in Gram Negative Bacteria. J Glob Infect Dis. 2010;2(3):263. [DOI:10.4103/0974-777X.68531] [PMID] [PMCID]

5. Meletis G. Carbapenem resistance: overview of the problem and future perspectives. Ther Adv Infect Dis. 2016;3(1):15-21. [DOI:10.1177/2049936115621709] [PMID] [PMCID]

6. Mulvey MR, Grant JM, Plewes K, Roscoe D, Boyd DA. New Delhi metallo- $\beta$-lactamase in Klebsiella pneumoniae and Escherichia coli, Canada. Emerg 

Infect
Dis.
2011;17(1):103 [DOI:10.3201/eid1701.101358] [PMID] [PMCID]

7. Coque TM, Baquero F, Canton R. Increasing prevalence of ESBL-producing Enterobacteriaceae in Europe. Euro Surveill. 2008;13(47):19044.

8. Goltsman G, Baumohl Y, Gal G, Buckman Z, Proshkin V, Lubart E. To check or not to check. Rectal ESBL colonization in hospitalized elderly patients. Am J Infect Control. 2018;46(11):1236-9. [DOI:10.1016/j.ajic.2018.05.010] [PMID]

9. Summers WC. Bacteriophage research: early history. Bacteriophages: Biology and applications. 2005:5-27. [DOI:10.1201/9780203491751.ch2]

10. Carlton RM. Phage therapy: past history and future prospects. Arch Immunol Ther Exp. 1999; 47:26774.

11. Summers WC. The strange history of phage therapy. Bacteriophage. 2012;2(2):130-3. [DOI:10.4161/bact.20757] [피] [ $\underline{\text { PMCID] }}$

12. Squires RA. Bacteriophage therapy for management of bacterial infections in veterinary practice: what was once old is new again. $\mathrm{N} \mathrm{Z} \mathrm{Vet}$ $\mathrm{J}$. 2018;66(5):229-35. [DOI:10.1080/00480169.2018.1491348] [PMID]

13. Furfaro LL, Chang BJ, Payne MS. Applications for bacteriophage therapy during pregnancy and the perinatal period. Front Microbiol. 2018; 8:2660. [DOI:10.3389/fmicb.2017.02660] [PMID] [PMCID]

14. LaVergne S, Hamilton T, Biswas B, Kumaraswamy M, Schooley RT, Wooten D. Phage therapy for a multidrug-resistant Acinetobacter baumannii craniectomy site infection. Open Forum Infect Dis. 2018;5(4). US: Oxford University Press. [DOI:10.1093/ofid/ofy064] [PMID] [PMCID]

15. Clark JR. Bacteriophage therapy: history and future prospects. Future Virol. 2015;10(4):449-61. [DOI:10.2217/fvl.15.3]

16. Kutter E, De Vos D, Gvasalia G, Alavidze Z, Gogokhia L, Kuhl S, Abedon ST. Phage therapy in clinical practice: treatment of human infections. Curr Pharm Biotechnol. 2010;11(1):69-86. [DOI:10.2174/138920110790725401] [PMID]

17. Loc-Carrillo C, Abedon ST. Pros and cons of phage therapy. Bacteriophage. 2011;1(2):111-4. [DOI:10.4161/bact.1.2.14590] [PMID] [PMCID]

18. Ajideh R, Faramarzi MA, Yazdi MH, Pourmand MR. Phage Therapy as a New Approach in Treating Emerging Antibiotic Resistant Infections. Trends Pept Protein Sci. 2018;2(1):15-23.

19. Wayne, P., Clinical and Laboratory Standards Institute (CLSI) performance standards for antimicrobial disk diffusion susceptibility tests 19th ed. approved standard. CLSI document M100-S19, 2009. 29(2011): p. M100-S21.

20. Hudzicki J. Kirby-Bauer disk diffusion susceptibility test protocol.2009.

21. Bourdin G, Schmitt B, Guy LM, Germond JE, Zuber S, Michot L, Reuteler G, Brüssow $\mathrm{H}$. Amplification and purification of T4-like Escherichia coli phages for phage therapy: from laboratory to pilot scale. Appl Environ Microbiol. 2014;80(4):1469-76. [DOI:10.1128/AEM.0335713] [PMID] [PMCID]

22. Yele AB, Thawal ND, Sahu PK, Chopade BA. Novel lytic bacteriophage AB7-IBB1 of Acinetobacter baumannii: isolation, characterization and its effect on biofilm. Arch Virol. 2012;157(8):1441-50. [DOI:10.1007/s00705012-1320-0] [PMID]

23. Santos SB, Carvalho CM, Sillankorva S, Nicolau A, Ferreira EC, Azeredo J. The use of antibiotics to improve phage detection and enumeration by the double-layer agar technique. BMC Microbiol. 2009;9(1):148. [DOI:10.1186/1471-2180-9-148] [PMID] [PMCID]

24. Carlson K, Miller E. Single-step growth. Molecular biology of bacteriophage. 1994. 4:434-7.

25. Popova AV, Zhilenkov EL, Myakinina VP, Krasilnikova VM, Volozhantsev NV. Isolation and characterization of wide host range lytic bacteriophage AP22 infecting Acinetobacter baumannii. FEMS Microbiol Lett. 2012;332(1):406. [DOI:10.1111/j.1574-6968.2012.02573.x] [PMID]

26. Birge EA. T4 bacteriophage as a model genetic system. In Bacterial and Bacteriophage Genetics 2000:171-214. [DOI:10.1007/978-1-4757-3258-0 6]

27. Brenner S, Horne RW. A negative staining method for high resolution electron microscopy of viruses. Biochim Biophys Acta. 1959; 34:103-10. [DOI:10.1016/0006-3002(59)90237-9]

28. Laemmli UK. Cleavage of structural proteins during the assembly of the head of bacteriophage T4. nature. 1970;227(5259):680-5. [DOI:10.1038/227680a0] [PMID]

29. Sen A, Ghosh AN. Physicochemical characterization of vibriophage N5. Virol J. 2005;2(1):1-4. https://doi.org/10.1186/1743-422X2-1 https://doi.org/10.1186/1743-422X-2-27 [DOI:10.1186/1743-422X-2-28] [PMID] [PMCID]

30. Grazziotin AL, Vidal NM, Palmeiro JK, DallaCosta LM, Venancio TM. Genome sequencing of four multidrug-resistant Enterobacter aerogenes isolates from hospitalized patients in Brazil. Front Microbiol. 2016; 7:1649. [DOI:10.3389/fmicb.2016.01649] [PMID] [PMCID] 
31. Paczosa MK, Mecsas J. Klebsiella pneumoniae: going on the offense with a strong defense. Microbiol Mol Biol Rev. 2016;80(3):629-61.

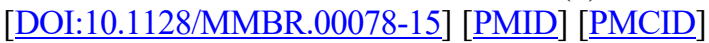

32. Vasilev K, Reshedko G, Orasan R, Sanchez M, Teras J, Babinchak T, Dukart G, Cooper A, Dartois N, Gandjini H, Orrico R. A Phase 3, open-label, non-comparative study of tigecycline in the treatment of patients with selected serious infections due to resistant Gram-negative organisms including Enterobacter species, Acinetobacter baumannii and Klebsiella pneumoniae. J Antimicrob Chemother. 2008;62(suppl_1): i29-40. [DOI:10.1093/jac/dkn249] [PMID]

33. Cosgrove SE, Kaye KS, Eliopoulous GM, Carmeli $Y$. Health and economic outcomes of the emergence of third-generation cephalosporin resistance in Enterobacter species. Arch Intern Med. 2002;162(2):185-90.

[DOI:10.1001/archinte.162.2.185] [PMID]

34. Podschun R. Phenotypic properties of Klebsiella pneumoniae and $\mathrm{K}$. oxytoca isolated from different sources. Int J Hyg Envir Heal. 1990;189(6):527-35.

35. Kropinski AM. Bacteriophage research-What we have learnt and what still needs to be addressed. Res Microbiol. 2018;169(9):481-7 [DOI:10.1016/i.resmic.2018.05.002] [PMID]

36. Krut O, Bekeredjian-Ding I. Contribution of the immune response to phage therapy. J Immunol. 2018;200(9):3037-44.

[DOI:10.4049/jimmunol.1701745] [PMID]

37. Kutateladze Á, Adamia R. Phage therapy experience at the Eliava Institute. Med Mal Infect. 2008;38(8):426-30. [DOI:10.1016/j.medmal.2008.06.023] [PMID]

38. Lin DM, Koskella B, Lin HC. Phage therapy: An alternative to antibiotics in the age of multi-drug resistance. World J Gastroentero. 2017;8(3):162. [DOI:10.4292/wjgpt.v8.i3.162] [PMID] [PMCID]

39. Schmelcher M, Shen Y, Nelson DC, Eugster MR, Eichenseher F, Hanke DC, Loessner MJ, Dong S, Pritchard DG, Lee JC, Becker SC. Evolutionarily distinct bacteriophage endolysins featuring conserved peptidoglycan cleavage sites protect mice from MRSA infection. J Antimicrob Chemother. 2015;70(5):1453-65. [DOI:10.1093/jac/dku552] [PMID] [PMCID]

40. Karumidze N, Kusradze I, Rigvava S, Goderdzishvili M, Rajakumar K, Alavidze Z. Isolation and characterisation of lytic bacteriophages of Klebsiella pneumoniae and Klebsiella oxytoca. Curr Microbiol. 2013;66(3):251-8. [DOI:10.1007/s00284-012-02647] [ $\underline{\mathrm{PMID}}]$
41. Komijani M, Bouzari M, Rahimi F. Detection and characterization of a novel lytic bacteriophage (vBKpneM-Isf48) against Klebsiella pneumoniae isolates from infected wounds carrying antibioticresistance genes (TEM, SHV, and CTX-M). Iran Red Crescent Med J. 2017. 19(2). [DOI:10.5812/ircmj.34475]

42. Zhao J, Zhang Z, Tian C, Chen X, Hu L, Wei X, Li $\mathrm{H}$, Lin W, Jiang A, Feng R, Yuan J. Characterizing the Biology of Lytic Bacteriophage vB_EaeM_ $\varphi$ Eap-3 Infecting Multidrug-Resistant Enterobacter aerogenes. Front Microbiol. 2019; 10:420. [DOI:10.3389/fmicb.2019.00420] [PMID] [PMCID]

43. Li E, Wei X, Ma Y, Yin Z, Li H, Lin W, Wang X, Li C, Shen Z, Zhao R, Yang H. Isolation and characterization of a bacteriophage phiEap-2 infecting multidrug resistant Enterobacter aerogenes. Sci Rep. 2017;7(6). [DOI:10.1038/srep46805] [PMID] [PMCID]

44. Ackermann HW. Phage classification and characterization in Bacteriophages 2009. Springer. 2009:127-140. [DOI:10.1007/978-1-60327-1646 13] [PMID]

45. Shahrbabak SS, Khodabandehlou Z, Shahverdi AR, Skurnik M, Ackermann HW, Varjosalo M, Yazdi MT, Sepehrizadeh Z. Isolation, characterization and complete genome sequence of PhaxI: a phage of Escherichia coli O157: H7. Microbiology. 2013;159(8):1629-38. [DOI:10.1099/mic.0.0637760] [PMID]

46. Tamakoshi, M., et al., Genomic and proteomic characterization of the large Myoviridae bacteriophage $\phi$ TMA of the extreme thermophile Thermus thermophilus. Bacteriophage, 2011:1(3):152-164. [DOI:10.4161/bact.1.3.16712] [PMID] [MCID]

47. Chibani-Chennoufi S, Dillmann ML, Marvin-Guy L, Rami-Shojaei S, Brüssow H. Lactobacillus plantarum bacteriophage LP65: a new member of the SPO1-like genus of the family Myoviridae. J Bacteriol. 2004;186(21):7069-83. [DOI:10.1128/JB.186.21.7069-7083.2004] [ $\underline{\text { PMID }] ~}$ [PMCID] 